\title{
Droughts and heatwaves in the Western Mediterranean: impact on vegetation and wildfires using the coupled WRF-ORCHIDEE regional model (RegIPSL)
}

\author{
Antoine Guion ${ }^{1} \cdot$ Solène Turquety ${ }^{1} \cdot$ Jan Polcher $^{2} \cdot$ Romain Pennel $^{2} \cdot$ Sophie Bastin $^{3} \cdot$ Thomas Arsouze $^{4}$
}

Received: 10 December 2020 / Accepted: 19 August 2021 / Published online: 14 September 2021

(c) The Author(s) 2021

\begin{abstract}
Droughts and heatwaves in the Mediterranean can induce plant activity decline and severe wildfires leading to considerable economic, social and environmental damages. This study aims at statistically quantifying the isolated and combined impacts of these extreme events based on a combination of regional land surface-atmosphere modeling and satellite observations of surface properties (MODIS). A simulation by the RegIPSL coupled regional model (ORCHIDEE-WRF) over the 1979-2016 period in the Western Mediterranean is used to identify heatwaves and droughts. After an evaluation of the model performance against surface observations of temperature and precipitation, a spatio-temporal analysis is conducted using specific indicators of extreme events: Percentile Limit Anomalies (PLA) and the Standardized Precipitation Evapotranspiration Index (SPEI). The impact on vegetation and wildfires is assessed using the MODIS observations of Leaf Area Index (LAI), burned area (BA) and fire radiative power (FRP), clustered by simulated extreme weather events. Due to water stress, droughts lead to significant biomass decrease (- $10 \%$ LAI on average and reaching $-23 \%$ in some areas). The isolated effect of heatwaves is smaller $(\sim-3 \% \mathrm{LAI})$ so that the combined effect is dominated by the impact of droughts. Heatwaves and droughts significantly exacerbate wildfire regimes. Through synergistic effects, simultaneous droughts and heatwaves increase BA and FRP by 2.1 and 2.9 times, respectively, compared to normal conditions. By reducing biomass, droughts slightly decrease fuel availability. However, our results show that the inter-annual variation in fire activity is mainly driven by weather conditions rather than fuel load.
\end{abstract}

Keywords Droughts · Heatwaves · Vegetation · Wildfire activity $\cdot$ Coupled land surface atmosphere model $\cdot$ MODIS observations · Western Mediterranean

Antoine Guion

antoine.guion@1md.polytechnique.fr

1 LMD/IPSL, Sorbonne Université, ENS, PSL Université, École polytechnique, Institut Polytechnique de Paris, CNRS, Paris, France

2 LMD/IPSL, École Polytechnique, Institut Polytechnique de Paris, ENS, PSL Université, Sorbonne Université, CNRS, Palaiseau, France

3 LATMOS/IPSL, Sorbonne Université, UVSQ, CNRS, Paris, France

4 LMD/IPSL, ENSTA ParisTech, ENS, PSL Université, École polytechnique, Institut Polytechnique de Paris, CNRS, Paris, France

\section{Introduction}

In line with what is expected in a context of global warming, droughts and heatwaves have increased both in frequency and severity over the last century in the Mediterranean area. Half of the 10 strongest heatwaves during the 1950-2014 period occurred between 2003 and 2014 in Europe (Russo et al. 2015). The 1990s and 2000s are the decades with the highest drought frequency and intensity over the 1950-2012 period in the Mediterranean (Spinoni et al. 2015). This trend is expected to continue over the 21 st century according to regional climate simulations from the EURO-CORDEX project (RCP4.5 and RCP8.5 scenarios) (Spinoni et al. 2018).

A heatwave is generally described as several days during which temperature is above seasonal average (e.g. Stéfanon et al. 2012b; Stegehuis et al. 2013). The definition of droughts is more complex and depends on the type of 
drought considered. There are meteorological, hydrologi$\mathrm{cal}$, and agricultural droughts with different related effects. These types of drought are manifested by, respectively, a rainfall deficit, a limited soil water reservoir for surface and underground flows, and a water shortage for plant growth (Vicente-Serrano et al. 2012; Svoboda et al. 2016).

The occurrence of these extreme events over the Mediterranean is directly linked to weather regimes at the synoptic scale with, for instance, the Atlantic Low and the Blocking regime, which bring warm and dry air in summer over the Mediterranean (e.g. Cassou et al. 2005; Stéfanon et al. 2012b). Summer droughts also depend on the rainfall between October and March (between 50 and $80 \%$ of annual rainfall) (Philandras et al. 2011; Xoplaki et al. 2004). At the meso-scale, the development of droughts and heatwaves are linked, mainly through the soil moisture-temperature feedback. A dry soil cannot provide latent heat cooling by evapotranspiration and, therefore, contributes to the warming of temperatures (Stéfanon et al. 2014). In addition, the dry convection favoured by hot days increases the height of the planetary boundary layer (PBL), leading to the development of upper anticyclonic conditions and increasing atmospheric stability (Zampieri et al. 2009). Droughts in the Mediterranean can also lead to heatwaves in continental Europe tempered by the northward transport of warm and dry air, with episodes of southerly winds (Vautard et al. 2007).

During such extreme conditions, vegetation is exposed to water and heat stresses. This can considerably affect plant development and vegetation activity, leading to a decrease of carbon uptake (e.g. Vicente-Serrano et al. 2013; Gouveia et al. 2017; Baumbach et al. 2017). For example, over the 1980-2010 period, $60 \%$ of the inter-annual variation of wheat production in Spain was attributed to these stresses (Zampieri et al. 2017). Severe wildfires can also result from extreme dry and hot weather conditions (e.g. Bowman et al. 2009; Turco et al. 2017; Duane and Brotons 2018) with considerable economic, social, and environmental damage. For instance, more than $7000 \mathrm{~km}^{2}$ burned in Mediterranean Europe during the record-breaking heatwave in 2003, compared to the annual average of $4500 \mathrm{~km}^{2}$ (Russo et al. 2015; Turco et al. 2016). The present study aims to assess the isolated and combined impacts of heatwaves and agricultural droughts on vegetation growth and wildfire activity in the Western Mediterranean region. Therefore, simulations by a coupled regional land surface-atmospheric model with interactive phenology (the RegIPSL model) are analyzed in conjunction with satellite observations of vegetation density (Leaf Area Index, LAI) and fire activity from the ModerateResolution Imaging Spectroradiometer (MODIS).

Quantifying the effect of droughts and heatwaves on vegetation is complex over the Mediterranean region since it depends on several parameters. The land cover with the associated vegetation type is one of them. Vicente-Serrano
(2007) showed that irrigated croplands and deciduous forests with deep root systems are less affected by plant activity decline in comparison to shrubs and pasture-lands (on the basis of correlation analysis between the drought and vegetation indicator). Moreover, each biome has its own sensitivity to the persistence of a water deficit. Vegetation in semi-arid biomes (e.g., Morocco and Andalusia) is affected by short-term droughts (3-6 months) because it responds quickly to water stress, whereas in temperate biomes (e.g., France) it is affected by larger droughts of 6-9 months (Vicente-Serrano et al. 2013). Although all Mediterranean biomes are susceptible to biomass reduction over several months (Guiot and Cramer 2016), semi-arid and arid environments are more prone to plant mortality (Vicente-Serrano et al. 2013). The season, and more specifically, the month of drought occurrence is another important factor. Gouveia et al. (2017) found that the strongest influence of drought on semi-arid biomes occurs in May because plant greenness peaks in spring, whereas it occurs in June-July for temperate biomes (maximum greenness in summer). Heatwaves can also induce a shift in vegetation phenology whose effect can vary seasonally, especially over the Northern Mediterranean (Baumbach et al. 2017). Extreme high temperatures can lead to a slight increase of the vegetation development in March-April, while it induces a strong decrease later in spring and in summer. Topo-climatic conditions are also fundamental, as they modify considerably the temperature and precipitation distribution (Vicente-Serrano 2007).

The variable chosen for the identification of drought is fundamental and may impact conclusions (Rivoire et al. 2019). Most studies use the Standardised Precipitation-Evapotranspiration Index (SPEI). However, it contains limited information about the real soil water content and vegetation state (Svoboda et al. 2016). Gathering 117 sampling points across the world, Vicente-Serrano et al. (2012) computed the correlation between SPEI and soil moisture. The mean coefficient was around 0.45 in spring and 0.55 in summer with the highest values reaching 0.85 . Moreover, information about water absorption by plant roots is missing in the SPEI. Even if this index, when compared to others, shows the best correlation with wheat yield over the Mediterranean, values ranged only from 0.2 to 0.6 (Vicente-Serrano et al. 2012). In this study, the coupled RegIPSL model, inherited from the MORCE-MED platform (Drobinski et al. 2012), is used in order to analyze both meteorological (temperature anomalies, SPEI) and hydrological variables (anomalies in soil dryness). The RegIPSL simulation has been performed for the 1979-2016 time period at $20 \mathrm{~km}$ spatial resolution, allowing an integration of the spatio-temporal dynamics of droughts, with inter-annual variability.

Finally, the RegIPSL simulation was performed with interactive phenology which allows it to account for the soil moisture - temperature feedback. Stéfanon et al. (2014) 
emphasized the need to perform long term simulations integrating meso-scale surface atmosphere exchanges. According to Fischer et al. (2007), such interactions contribute to an increase of heatwave duration and account for $50-80 \%$ of the number of summer hot days. Furthermore, interactive phenology of the vegetation is important for the simulation of drought and heatwave processes. Water-stressed vegetation can amplify heatwaves by land surface heating. The opposite effect (heatwave dampening) is possible in situations of enhanced evapotranspiration and surface cooling. Stéfanon et al. (2012a) showed that dynamic vegetation can modify the 2003 summer heatwave assessment by $\pm 1.5^{\circ} \mathrm{C}$, i.e. $20 \%$ of its magnitude. The methodology chosen here aims at evaluating the isolated and combined effects of heatwaves and droughts on vegetation using the LAI as the indicator.

In addition to the impact on vegetation, meteorological conditions play a major role on the intensity of wildfire events. Strong winds and hot days favour fire propagation. Duane and Brotons (2018) identified 3 out of the 6 weather regimes at the synoptic scale control wildfire activity driven by strong winds: the Scandinavian Low, the Atlantic Ridge, and the Atlantic Low, the last is also favorable for heatwaves (Cassou et al. 2005).

Droughts can influence the wildfire activity through two factors: fuel availability and fuel dryness. On one hand, a precipitation deficit during the wet season (November-May) and early summer (June) inhibits vegetation growth and thereby reduces the fuel load (Sarris et al. 2014; Gouveia et al. 2016). On the other hand, droughts during the fire season (June-September) decrease the fuel moisture (Turco et al. 2017). The effect of drought on fuel dryness could be offset by a reduction in fuel availability leading to a limited fire intensity.

However, there are many uncertainties as to which effect predominates (Turco et al. 2017). Moreover, human influence can be considerable. Even if an increase in wildfire risk is simulated in response to climate change (Moriondo et al. 2006), trends of wildfire activity over the Mediterranean were negative in the past few decades, with a total decrease of $3020 \mathrm{~km}^{2}$ burned area (i.e - 66\%) over the 1985-2011 period (Turco et al. 2016). This is mainly due to efforts in improving fire suppression (direct anthropogenic drivers), and fire management and prevention (indirect drivers). Nevertheless, human control over mega-fires is limited and these extreme fire events are mainly driven by weather conditions and fuel availability. In order to understand the dominant factors in the Western Mediterranean region, it is therefore important to take into account both meteorological conditions and the response of vegetation to extreme events. In this study, the impact of heatwaves and droughts on wildfires is analyzed using satellite fire activity observations from MODIS, combined with meteorological conditions simulated by the RegIPSL simulations.
In the second section of the manuscript (Sect. 2), the observations of temperature and precipitation used to validate the RegIPSL model are presented (E-OBS dataset), as well as the satellite observations used to track the evolution of vegetation (LAI product) and fire activity. The regional coupled RegIPSL model is then presented, and the simulation performed for south-western Europe (Med-CORDEX) is evaluated against observations (see Sect. 3). After a presentation of the methods used for the identification of extreme events (see Sect. 4), the simulated spatio-temporal patterns of droughts and heatwaves are identified and then characterized both in frequency and intensity (see Sect. 5). Finally, their effect on observed plant biomass (using the LAI) and wildfire activity is discussed (see Sect. 6). LAI variation from MODIS is compared to the simulated one by Med-CORDEX.

\section{Observations}

\subsection{E-OBS near surface air temperature and precipitation}

The E-OBS dataset (version 16.0) (Cornes et al. 2018) is used for the validation of the RegIPSL simulation (see Sect. 3.2.1). It is a daily gridded dataset of standard meteorological observations constructed as part of the European Climate Assessment \& Dataset project. It provides air temperature at 2 meters above surface $\left(T_{2 m}\right)$ and precipitation variables for the 1950-2018 period over Europe. The data points from the Pan-European network of measurement stations are interpolated onto a grid of resolution $0.25^{\circ} \times 0.25^{\circ}$, in three steps. First, thin-plate splines are applied over the monthly mean data in order to create a spatial trend. Then, the daily anomalies of the monthly mean are interpolated using a Kriging method. Finally, the daily and monthly data are combined (Haylock et al. 2008).

The uncertainty of the E-OBS dataset can be considerable for some variables. For instance, Hofstra et al. (2009) showed that the percentage of data exceeding the $95 \%$ confidence interval can range from 10 to $25 \%$ in the Mediterranean for the observed minimum temperature. The two main sources of uncertainty are the stochastic method of interpolation and the spatial distribution of the measurement stations. Cornes et al. (2018) assessed the uncertainty between interpolated values and 100 reference stations of E-OBS over the 1950-2016 period. They computed an annual mean absolute error of $0.80{ }^{\circ} \mathrm{C}, 1.22{ }^{\circ} \mathrm{C}, 0.92{ }^{\circ} \mathrm{C}$ respectively for the mean, minimum and maximum temperature and of $0.92 \mathrm{~mm} /$ day for the rainfall rate. The Southern Mediterranean is not as well covered as other parts of the region. Hofstra et al. (2009) compared the E-OBS precipitation dataset 
with denser station network datasets of observations for Europe (ELDAS product) and, more specifically, over the Alps. The ELDAS precipitation product covers a relatively short period (2000-2001) in comparison to E-OBS. Even if they found good correlation between the different datasets ( $\mathrm{R}$ coefficient between 0.85 and 0.88 ), considerable annual mean absolute errors were computed: $1.16 \mathrm{~mm} /$ day over Europe and $2.25 \mathrm{~mm} /$ day specifically over the Alps.

Besides the heterogeneous spatial distribution of the stations, their total number varies over time. The mean standard error in spatial average is higher $\left(0.72{ }^{\circ} \mathrm{C}\right)$ at the beginning (1950-1960) than at the end (1990-2000) of the period $\left(0.66^{\circ} \mathrm{C}\right)$, due to an increase in the number of stations. However, this error increased after 2000 due to a $20 \%$ decrease of the number stations. The error was estimated to be $0.70{ }^{\circ} \mathrm{C}$ in 2008 . Furthermore, uncertainty estimates have seasonal variation: the standard error is higher in spring and lower in autumn, representing a difference of $0.4{ }^{\circ} \mathrm{C}$ (Haylock et al. 2008).

\subsection{MODIS Leaf Area Index}

The evolution of vegetation density is analyzed using the Leaf Area Index (LAI) reconstructed from the MODIS (Moderate-Resolution Imaging Spectroradiometer) instrument. MODIS is carried onboard both TERRA (launched in 2000) and AQUA (launched in 2003) polar orbiting satellites. A complete screening of the globe is performed every 2 days.

The MCD15A3H product (Myneni et al. 2015) provides the LAI with a 4 day temporal resolution and 500 meter horizontal resolution. LAI is computed from the Normalized Difference Vegetation Index (NDVI) by empirical relationship (Knyazikhin et al. 1998), which is derived from observations in the red channel (648nm) and the near infrared channel $(858 \mathrm{~nm})$. The uncertainty of the land surface Bidirectional Reflectance Factor (BRF) used for NDVI computation is estimated between 20 and $30 \%$ for the red channel and between 5 and $15 \%$ for the near infrared channel, depending on the vegetation type (Myneni et al. 2015). Moreover, cloud cover can block NDVI measurement, resulting in missing data.

The estimated LAI from MODIS can show considerable differences with the LAI observed at the surface. Sprintsin et al. (2009) compared the MODIS LAI to ground-based measurements over a Mediterranean dryland forest over 2 years at monthly time steps. The summer MODIS LAI $\left(0.6 \mathrm{~m}^{2} / \mathrm{m}^{2}\right)$ was almost three times smaller than the LAI measurements (1.7). The monthly standard error of MODIS LAI was estimated at about 0.17 .

\subsection{MODIS fire characteristics}

Two MODIS products are used to study the wildfire activity. The MODIS MOD14 product provides the location of the thermal anomalies and the associated Fire Radiative Power (FRP) at $1 \mathrm{~km}$ resolution (Giglio et al. 2006). The Burned Area (BA) product MCD64 provides the date of burning based on burn scars at $500 \mathrm{~m}$ resolution (Giglio et al. 2010). The uncertainty of fire and burn scar detection is mainly due to cloud cover, which prevents the observation of the surface properties. The estimated uncertainty of the date of burning is about 2 days (Giglio et al. 2018). Dense aerosol plumes from wildfires may also attenuate the signal resulting in underestimated FRP.

The total annual burned area estimated from the MODIS product has been compared to that reported by the European Forest Fires Information System (EFFIS) program (San-Miguel-Ayanz et al. 2012) for the years of 2003-2016. The difference is equal to $215 \mathrm{~km}^{2}$ on average over Southern Europe (not shown) and can reach $270 \mathrm{~km}^{2}$ on average in Portugal (up to almost $2500 \mathrm{~km}^{2}$ in 2003). The MODIS burned area tends to be higher than the EFFIS burned area. However, the temporal correlation between both datasets is high $(\sim 0.9)$ for each country. This is consistent with the analysis by Turco et al. (2019) who found temporal correlations of 0.95 for the annual total burned area (2001-2011 period) between MODIS and EFFIS for several countries of Southern Europe. In spite of the uncertainties, the interannual variability is thus well represented in the MODIS data.

The type of vegetation burned is identified using the MODIS MCD12 product at $500 \mathrm{~m}$ spatial resolution (Friedl et al. 2010). The MODIS datasets are processed using the APIFLAME model (Turquety et al. 2020) in order to derive daily BA and FRP distributions over the RegIPSL domain. Figure 1 shows the spatial distribution of yearly summer burned area (JJA) during the 2003-2016 period, as well as the frequency of burning. The Western Iberian Peninsula, Maghreb, and Balkans sub-regions are characterized by a total yearly burned area higher than $20000 \mathrm{ha}$, with at least half of the summers affected by wildfires during 2003-2016. Those areas, in addition to Southern France, Spain, and Italy, will be investigated in more detail in Sect. 5 and 6, as they are highly affected by wildfires and representative of different biomes. We consider Southern Spain and the Maghreb as semi-arid biomes and the others as temperate biomes. The chosen sub-regions include about $82 \%$ of fires detected in the Western Mediterranean area. 36\% of these fires are detected in Western Iberian Peninsula. The vegetation types most affected by fires in the Western Mediterranean are temperate forests, grassland, and agriculture. For each sub-region, grasslands are the most affected (between $46 \%$ in the Balkans and 65\% in Southern Spain). The largest 


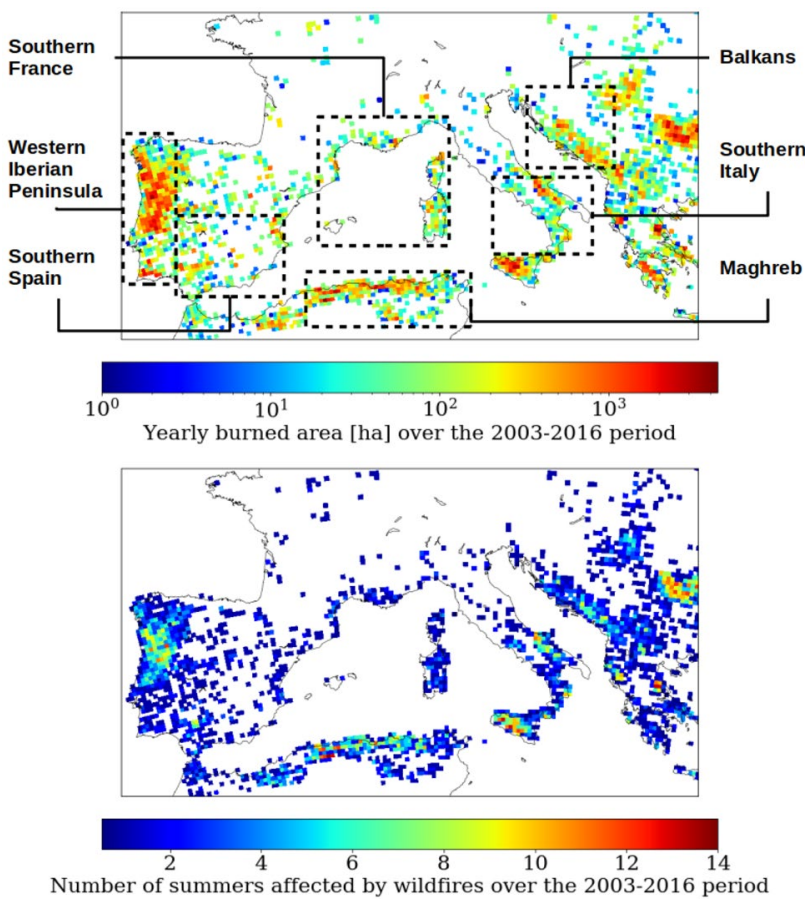

Fig. 1 Total yearly summer burned area (JJA) above 1ha (top panel) and number of summers affected by wildfires (bottom panel). For diagnostic purposes, sub-regions are designated (dashed rectangles) within the Western Mediterranean region

percentage of temperate forests (28\%) is found in the west of the Iberian Peninsula and the lowest in Southern Italy (6\%). Burned agricultural areas vary considerably between sub-regions (by more than 35\%).

The effects of droughts, heatwaves, and wind gusts on wildfire activity are analyzed using three metrics derived from MODIS observations: total Burned Area (BA), maximum Fire Radiative Power (FRP) as a surrogate for fire intensity and mean Fire Duration (FD). In order to study the fire mainly driven by natural conditions, we exclude fires lasting less than 1 day and burned areas less than $1 \mathrm{~km}^{2}$. Moreover, at the scale considered, fires in adjacent grid cells and separated by less than 2 days are considered as one fire event.

\section{Coupled WRF-ORCHIDEE regional model (RegIPSL)}

\subsection{Model description}

The regional Earth system model of the Institut Pierre Simon Laplace (IPSL), an improved version of the MORCE-MED platform (Drobinski et al. 2012), couples the land surface model ORCHIDEE (ORganising Carbon and Hydrology In Dynamic EcosystEms), the atmospheric model WRF
(Weather Research and Forecasting), and the ocean model NEMO (Nucleus for European Modelling of the Ocean). The simulation performed for this study does not use the interactive oceanic component.

The WRF limited area atmospheric model is used for operational forecasting as well as climate research (Skamarock et al. 2008). The ARW (Advanced Research WRF) non-hydrostatic dynamical core was selected together with a set of physics packages appropriate for resolutions of about $20 \mathrm{~km}$. These include in particular the singlemoment 5 class microphysics scheme (Hong et al. 2004), which produces the clouds and their properties in interaction with the radiation scheme developed by Iacono et al. (2008). Convection is parametrized at these resolutions with the Kain-Fritsch scheme (Kain 2004) and the shallow convection scheme proposed by Park and Bretherton (2009). The interaction with the surface occurs through the Mellor-Yamada Level-3 representation of boundary layer turbulence, developed by Nakanishi and Niino (2009). These are standard parametrizations within WRF and were thoroughly tested over the Mediterranean region by Di Luca et al. (2014).

An original feature of this regional Earth system model is that the land surface model, ORCHIDEE, is coupled to the atmosphere through the OASIS coupler (Craig et al. 2017) using the methodology described in Polcher et al. (1998). Because of the fast processes involved in this coupling, the same spatial grid and time step are used for the atmospheric and land surface components.

ORCHIDEE is the the Dynamic Global Vegetation Model developed at IPSL (Maignan et al. 2011). It includes three different modules (SECHIBA, STOMATE and LPJ) which resolve, respectively, the processes of the energy and water cycle, the carbon cycle and the evolution of the vegetation (Fig. 2). SECHIBA solves the surface energy balance equation for which it has to compute the various exchanges of water and energy between the biosphere and the atmosphere. It is the component through which the interactions with the atmosphere occur (Krinner et al. 2005). STOMATE is the biophysical component of the mode. It simulates the carbon exchanges over the continent, i.e. the sub-seasonal dynamics and phenology (budburst, senescence, and vernalisation) of the vegetation. LPJ, which is not used for this research, is the dynamic module of the vegetation. It describes the competition between the different Plant Functional Type (PFT) at a temporal resolution of 1 year. ORCHIDEE categorizes vegetation in 13 PFT (Fig. 3), the distribution of which is derived from the ESA-CCI (European Space Agency-Climate Change Initiative) database (ESA 2017). Biophysical and biochemical variables are computed for each PFT. Parameters attributed to the vegetation (e.g. root length profile and maximum LAI) are PFT-specific. The soil is composed of 11 layers (De Rosnay et al. 2002). Soil 


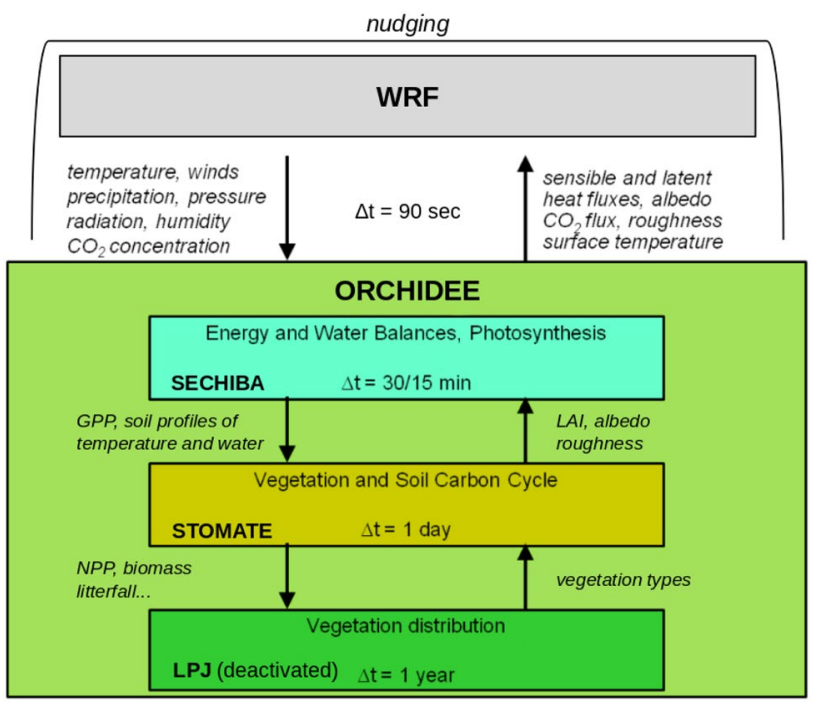

Fig. 2 The RegIPSL coupling flow chart. This figure is inspired by the IPSL online documentation (https://orchidee.ipsl.fr/)

organic matter, minerals, and water can be transferred to the underlying layers.

For the present study, a configuration of RegIPSL was chosen to comply with the recommendation of the MedCORDEX initiative (Ruti et al. 2016), a contribution to CORDEX (Coordinated Regional Climate Downscaling Experiment). The domain covers the Euro-Mediterranean. The chosen resolution is $20 \mathrm{~km}$ on a Lambert-conformal projection. For the vertical dimension, 46 levels were chosen with over half below $500 \mathrm{hPa}$. The simulation covers the 1979-2016 period with the ERA-I reanalysis being used to drive the atmosphere at its lateral boundaries. In order to avoid too large of a divergence of the internal solution in the atmosphere and the boundaries, the wind and temperature at scales above $1200 \mathrm{~km}$, in the levels above the planetary boundary, were also nudged towards the ERA-I reanalysis. It was shown by Omrani et al. (2015) that this improves the quality of the simulation over the entire domain. To start the simulation with land surface state variables in equilibrium with the atmosphere, we have used the output of a long MedCORDEX simulation as the initial conditions.

The study proposed here will focus on the Western Mediterranean area, where a large knowledge base of droughts and wildfires is available. Figure 3 shows the dominant PFTs present in our study area. C3 agriculture is mainly located at low altitude over plains, while $\mathrm{C} 3$ grass and temperate forests are dominant on topographical features. For this research, the needleleaf and broad-leaved forests will be aggregated into a single class called "temperate forests".

\subsection{Validation of the Med-CORDEX simulation}

\subsubsection{Temperature and precipitation}

The simulated temperature at $2 \mathrm{~m}$ above surface $\left(T_{2 m}\right)$ is evaluated by comparisons with the E-OBS database. For the 1979-2016 period simulated here and during the summer (June-July-August), the average daily mean simulated $T_{2 m}$ is overestimated by $\sim 2-3{ }^{\circ} \mathrm{C}$ over most of the Western Mediterranean (Supplementary Material: Fig. 12). The bias is highest over the Southern Mediterranean $\left(5-6^{\circ} \mathrm{C}\right)$ and negative over topographic relief (Alps and Pyrenees, -1 to $\left.-2{ }^{\circ} \mathrm{C}\right)$, where the uncertainty on the gridded dataset is higher (see Sect. 2.1). On average over the Western Mediterranean, the $T_{2 m}$ time series (SM: Fig. 13) show that the
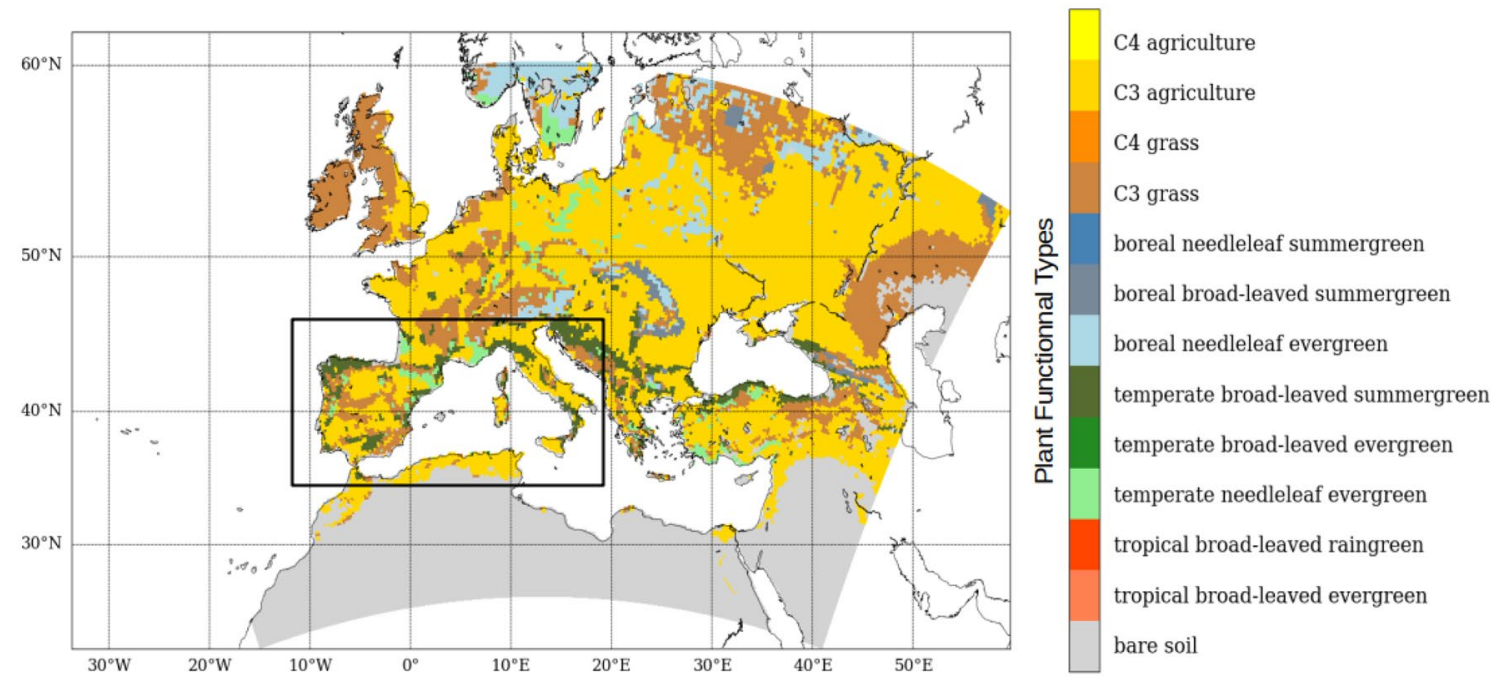

Fig. 3 Dominant PFT vegetation over the domain of Med-CORDEX simulation. The Western Mediterranean region studied here is shown in black 
simulated daily mean $T_{2 m}$ is overestimated by $1.75-2.0{ }^{\circ} \mathrm{C}$, when compared to observations, there is no bias on the daily maximum $T_{2 m}$, and the daily minimum $T_{2 m}$ is overestimated by $2.5-3.25^{\circ} \mathrm{C}$. The correlation coefficient between observations and simulations is $\sim 0.96$ for the minimum $T_{2 m}$, and $\sim 0.98$ for the mean and maximum $T_{2 m}$.

During winter (December-January-February), the bias is less pronounced and more spatially heterogeneous. The time series show that the $T_{2 m}$ bias is within the range of the E-OBS standard error $\left(\sim 0.7{ }^{\circ} \mathrm{C}\right)$. The correlation coefficient is slightly lower in winter $(\sim 0.90)$ than in summer for the minimum $T_{2 m}$. It is similar for the mean and maximum $T_{2 m}$ $(\sim 0.98)$. The largest standard error of the bias is obtained for the minimum $T_{2 m}\left(0.10{ }^{\circ} \mathrm{C}\right.$ in winter and $0.07{ }^{\circ} \mathrm{C}$ in summer).

In order to understand the bias of $T_{2 m}$, the seasonal distribution of the energy budget in Med-CORDEX was analyzed, as the seasonal temperature is mainly controlled by surface fluxes. Compared to the results presented by Pfeifroth et al. (2018), based on the SARAH-2 and CLARA-A2 satellite climate datasets and over the same time period (1992-2015), the average Med-CORDEX downward solar radiation reaching the surface is about $20 \mathrm{~W} / \mathrm{m}^{2}$ higher over most of the domain (not shown). As shown by Chakroun et al. (2018), this overestimation could be due to a lack of low clouds, especially in summer. Low aerosol concentration may reinforce the bias. Bastin et al. (2018) found similar results for a regional WRF climate simulation over the Mediterranean when compared to ground-based observations (lidar station).

Compared to the E-OBS database, the simulated summer rainfall rate is, on average, slightly overestimated, from 0.1 up to $0.6 \mathrm{~mm} /$ day, depending on the year (SM: Fig. 14). During winter, the average simulated precipitation in the area is underestimated (SM: Fig. 14). The bias decreases along the simulation period, from $-0.4 \mathrm{~mm} /$ day in 1984 to $-0.1 \mathrm{~mm} /$ day in 2015. Unlike summer, the winter bias pattern is heterogeneous (SM: Fig. 15). The biggest bias is obtained over the Alps ( $\sim 5 \mathrm{~mm} /$ day). The correlation coefficients, 0.85 in summer and 0.9 in winter, show the ability of the model to capture the temporal variations.

The rainfall rate bias obtained, with a low standard error (5 to $10 \%$ ), is in the range of validation values from other analysis in the literature (see Sect. 2.1). The overestimated summer rainfall by WRF was also found by Herwehe et al. (2014) and Katragkou et al. (2015) for the United States and Europe. They suggested that the overestimated downward shortwave radiation implies an excess of latent heat flux which triggers an overestimate of the summertime convective precipitation through the Kain-Fristch convective scheme.

The simulated cloud cover fraction is close to 0.1 on average over the summer and 0.5 in winter (not shown). This seasonal variability in cloud cover is higher than that found by Ioannidis et al. (2018) using the NCEP/NCAR reanalysis for the period 1948-2014 (amplitude of 0.15-0.2, depending on the area). However, Chakroun et al. (2018) simulated with WRF a seasonal variability of cloud profiles over Europe, similar to space lidar observations (CALIPSO) for the period 2006-2011.

The simulated wind speed is also analyzed in this study for their role on wildfire activity (e.g. Beer 1991; Duane and Brotons 2018). Since it is not central to this study, a full validation is not shown here. However, previous studies using the regional atmosphere/ocean coupled model WRF/ NEMO-MED12, with similar configuration (HyMeX/MEDCORDEX simulations using ERA-Interim reanalysis), has demonstrated a satisfying reproduction of the intensity, direction and inland penetration of the sea breeze (mean accuracy of 5-20\% for those characteristics) over the Northwestern Mediterranean area (Drobinski et al. 2018).

\subsubsection{Leaf Area Index}

The simulated LAI was evaluated by comparison with MODIS satellite observations of the 4-day mean LAI. The MODIS LAI was gridded over the Med-CORDEX domain and smoothed (Hanning window) to avoid any artificial variability that might be due to the representation of the data in grid cells. The simulated LAI was averaged over the 4-day observation periods, and only grid cells with coincident observations were considered.

Timeseries of 4-days LAI, averaged over the Western Mediterranean, are shown in SM (Fig. 16). Significant differences between simulated and observed LAI are obtained. In particular, the amplitude of the seasonal variation is larger in the simulation. On average, over the period, the MedCORDEX LAI varies between 2.25 (summer) and 0.40 (winter) while the MODIS LAI varies between 1.25 (summer) and 0.60 (winter). The decrease of LAI from June to August is stronger in the simulation $(-40.0 \%)$ than in the observations $(-15.3 \%)$. As a result, the LAI bias decreases: +0.91 units on the 1 st of June and +0.24 units on the 31st of August. The spatial distribution of the summer bias of LAI is homogeneous ( 2.0) over the Northern Mediterranean. It is much lower and more heterogeneous in semiarid areas (between -0.5 and 0.5), such as over Southern Spain or Maghreb (SM: Fig. 17). Differences at the regional scale could be partly explained by the overestimated downward shortwave flux in RegIPSL during the summer, since exceeding solar energy can boost vegetation growth. It may also be due to different representations of phenology. However, the intra- and inter-annual variation are spatially and temporally similar. The temporal correlation between both LAI is high (between 0.5 and 0.8 ) over most of the Western Mediterranean as well as for the semi-arid areas (not shown). 
Caldararu et al. (2014) found a similar LAI seasonal amplitude with the MODIS instrument in the Mediterranean $(\sim 0.7)$. Even if Chakroun et al. (2014) identified a low summer variation of the intra-annual MODIS LAI, they demonstrated that MODIS captures accurately the inter-annual variability of summer LAI response due to drought for most of the Mediterranean forests. However, Sprintsin et al. (2009) highlighted significant discrepancies between MODIS LAI and groundbased measurements for dry forests due to a lack of distinction at high resolution between land cover elements which can be highly heterogeneous and sparse over the semi-arid areas. In this case, the seasonal variation of MODIS LAI during the summer is too weak. Summer overestimation of simulated LAI from vegetation models in comparison to MODIS LAI was found in several previous studies; between 0.5 and 1 over the Mediterranean with ORCHIDEE (Demarty et al. 2007), and between 1 and 2 over the United States (Indiana) with the crop growth model CSM-CERES-Maize (Fang et al. 2011) as examples.

The impact of droughts and heatwaves on vegetation was evaluated using the MODIS LAI primarily, but also from the Med-CORDEX LAI for comparison and to access PFTdependent information. In order to compare the amplitude of the responses to heat and water stress both in absolute and relative values, the amplitude of the simulated LAI has been scaled to that of the observations (SM: Fig. 16).

\section{Indicators of extreme weather events}

Several indicators have been calculated based on the simulated parameters or the E-OBS meteorological dataset in order to identify time periods affected by extreme events during the summer: heatwaves, droughts, and wind gusts.

Meteorological droughts may be identified using the Standardized Precipitation Evapotranspiration Index (SPEI method). Developed by Vicente-Serrano et al. (2010), it is based on the Standardized Precipitation Index (SPI) (McKee et al. 1993) but also includes temperature information through the potential evapotranspiration. For each region (or model grid cell) and for a given month $m$, the water balance is calculated as the difference between the accumulated monthly precipitation $P_{m}$ and the potential evapotranspiration $P E T_{m}$ :

$D_{m}=P_{m}-P E T_{m}$

When $D_{m}$ is positive, the excess water (called useful water) can generate runoff and infiltration into the unsaturated soil and thus be available for plant transpiration. When $D_{m}$ is negative, the considered month is in a deficit. The water balance can be accumulated over several months, including a certain number of months before month $m$. Here $D_{m}$ was computed over periods of 3,6 and 12 months. An index of 0 represents normal conditions (average value of SPEI). A negative (positive) index means that the studied period is dryer (wetter) than normal conditions. The standard deviation is 1 . The SPEI gives information on the drought severity through its intensity and approximate duration if the index is below -1 for consecutive months. SPEI is commonly used to analyze the intensification of drought severity related to precipitation reduction in the context of climate change (Vicente-Serrano et al. 2010). However, it is less suitable in semi-arid conditions because the limiting factor is then water availability rather than energy, considered in PET.

Therefore, for agricultural drought detection, we chose to construct a drought indicator based on soil dryness using the Percentile Limit Anomalies $\left(P L A_{S D}\right)$. The soil dryness is defined as the complement of the Soil Wetness Index (SWI) computed by ORCHIDEE:

$S W I=\frac{W_{c}}{C}$

where $W_{c}$ is the ground water content and $\mathrm{C}$ the soil moisture capacity. This index is convenient for ecologically heterogeneous regions. The water holding capacity of a soil depends largely on its composition. The soil dryness index is then $S D I=1-S W I$ and varies between 0 (saturated) and 1 (totally dry).

The PLA method is also used for heatwave detection based on the $2 \mathrm{~m}$ above surface temperature $\left(P L A_{T 2 m}\right)$, and for wind gust detection based on the $10 \mathrm{~m}$ above surface wind speed $\left(P L A_{w 10}\right) . T_{2 m}$ has been detrended to detect the anomaly as extreme weather. For each cell of longitude $(i)$ and latitude $(j)$ in the considered area, the monthly distribution of the variable is normalized. For each month $(m)$, the corresponding percentiles $(p)$ are computed for the 1979-2016 period. Here $p$ is set at 0.75 , to allow a large statistical population. Finally, the daily deviation $\left(d X_{i, j, d}\right)$ between the $2 \mathrm{~m}$ temperature/soil dryness/wind speed $\left(X_{i, j, d}\right)$ and the monthly percentile $\left(X_{i, j, m}^{p}\right)$ is computed cell by cell for the day $(d)$ as follows:

$d X_{i, j, d}=X_{i, j, d}-X_{i, j, m}^{p}$

Equation 3 allows the analysis of spatial patterns and highlights local variability. If the spatial sum of $d X_{i, j, d}$ over the chosen area is positive, an extreme day is identified. An extreme event is defined as three consecutive extreme days. The intensity of the extreme event $(I)$ is equal to the average of its anomalies :

$I=\frac{\sum_{i, j} d X_{i, j, d}}{N}$

where $N$ is the number of cells in the considered area.

The value of the computed percentile depends on the distribution of the normalized range of values. This feature 
allows us to apply this method for different regions and is suitable for comparative studies as it accounts for local variability (Lhotka and Kysely 2015). Note that the higher the percentile that is established, the more extreme the event. To analyze the synergetic effects of heatwaves and droughts, soil dryness and temperature anomalies $\left(P L A_{S D}\right.$ and $\left.P L A_{T 2 m}\right)$ have been combined $\left(P L A_{S D, T}\right)$. Therefore, each anomaly distribution has been standardized before being combined.

The SPEI and $P L A_{S D}$ methods are complementary and provide information on different drought types. SPEI is generally used to identify the meteorological droughts and $P L A_{S D}$ is more appropriate for agricultural droughts. The soil dryness in ORCHIDEE is directly computed from the soil water budget and therefore depends on the soil (water infiltration) and vegetation type (root absorption and plant transpiration) instead of the weather conditions. The spatial distribution of droughts identified by the SPEI is representative of different climate regions while drought patterns identified by $P L A_{S D}$ (more heterogeneous) provides information depending on the sub-regional vegetation and soil distribution, which can vary at local scale. Moreover, both methods represent different time scales: while the PLA method considers the inter-annual variability (conditions during one specific month are compared to the distribution of the same month during the full time-period), SPEI focuses on the intra-annual variability (from 3 to 12 months of accumulation in the considered year).

The indicators of extreme temperature and soil dryness are used to isolate events and analyze the spatial structures and temporal variations of drought and heatwave characteristics (intensity and frequency) in Sect. 5, based on both the PLA and SPEI method. Their impact on vegetation and wildfires in Sect. 6 is assessed based on the PLA method. To study the relationship between vegetation growth and heatwaves and droughts, the correlation between LAI and the indicators $P L A_{T 2 m}, P L A_{S D}$ and $P L A_{S D, T}$ are computed for each grid cell. Since wildfires are very sporadic in the region, a cluster approach was used to characterize the impact of extremes (see Sect. 6.2.1). Based on the indicator values (PLA method), the detected events were classified to construct samples corresponding to periods of heatwaves, droughts, and strong winds (isolated or combined).

\section{Frequency and intensity of droughts and heatwaves}

\subsection{Regional structures}

Figure 4 shows the simulated spatial distribution of the mean percentile values ( $T_{2 m}$ and SD) during the summer (JJA), the mean intensity and the frequency (fraction of summer days) of intense heatwaves $\left(P L A_{T 2 m}>1{ }^{\circ} \mathrm{C}\right)$ and of droughts
( $P L A_{S D}>0.02$ of soil dryness). Heatwave and drought patterns are directly sensitive to the distribution of the 75th percentile value as the background threshold.

Heatwaves are the most intense $\left(+2{ }^{\circ} \mathrm{C}\right.$ above the 75 th percentile value) and frequent (about $17 \%$ of days for intense events) over the western part of the domain (Western Iberian Peninsula and Western France), Northern Africa (Northern Algeria and Tunisia) and the Pannonian Plain (mostly Hungary with Northern Serbia and Western Romania).

The PLA method was also applied to the E-OBS $T_{2 m}$ for validation. Observed heatwaves show similar regional structures to the simulated ones, especially concerning their frequency (not shown). However, the intensity of observed heatwaves is, in general, slightly lower (SM: Fig. 18). Computing the mean bias of heatwave characteristics between Med-CORDEX and E-OBS, we found a bias of $+0.16^{\circ} \mathrm{C}$ for the intensity, +0.07 for the fraction of days, and +0.03 days for the longest event. The temporal correlation coefficient between simulated and observed $P L A_{T 2 m}$ is around 0.9 over the study area, except over Northern Africa where it is lower (0.5) (not shown). In conclusion, despite the constant positive bias of simulated $T_{2 m}$ (Sect. 3.2.1), RegIPSL is suitable for simulating heatwaves since extreme conditions (peaks) are well represented.

Droughts are more spatially heterogeneous than heatwaves because, beyond climatic forcing, vegetation and soil type also have an important influence. The Pannonian Plain is affected by intense ( $+5 \%$ of soil dryness) and frequent droughts (about 20\% of the summertime for events with $\left.P L A_{S D}>2 \%\right)$. Northern Italy is also affected by intense droughts. Similar to heatwave patterns, drought patterns have to be analyzed in conjunction with the percentile values. For example, in Northern Africa, soil dryness percentile is high, which results in a low mean intensity and frequency of events.

Figure 5 shows the monthly frequency of low summer SPEI $(<-1)$, calculated with 6 months of accumulation, characterizing meteorological droughts during the 1979-2016 period. Southern Spain and inland Algeria and Tunisia (with dominant bare soil) are the areas most affected by droughts (frequency of occurrence between 20 and 30\% of summer months). Droughts are also very frequent over the Pannonian Plain, as obtained using the $P L A_{S D}$ method.

The spatial extent of droughts varies with the time scale and period of analysis (e.g. Vicente-Serrano et al. 2013; Gouveia et al. 2017). With 12 months of accumulation of water balance $\left(D_{m}\right)$ in the calculation of the SPEI, clear distinction between semi-arid (Andalusia and Northern Africa) and temperate biomes (Northern Mediterranean) can be noticed (not shown). In the Northern Mediterranean, drought frequency decreases with increasing number of accumulated months: from $20 \%$ of summertime with 3 months to $10 \%$ with 12 months, because it covers the entire wet season. 
Fig. 4 Heatwaves (left column) and droughts (right column) identified using the Percentile Limit Anomalies (PLA) method. The first row shows the 75 th percentile value during summer (JJA average), the second row shows the mean intensity of the extreme events, and the last row shows the frequency (over the total number of summer days) of intense events $\left(>1{ }^{\circ} \mathrm{C}\right.$ for heatwaves and $>0.02$ of soil dryness for droughts)
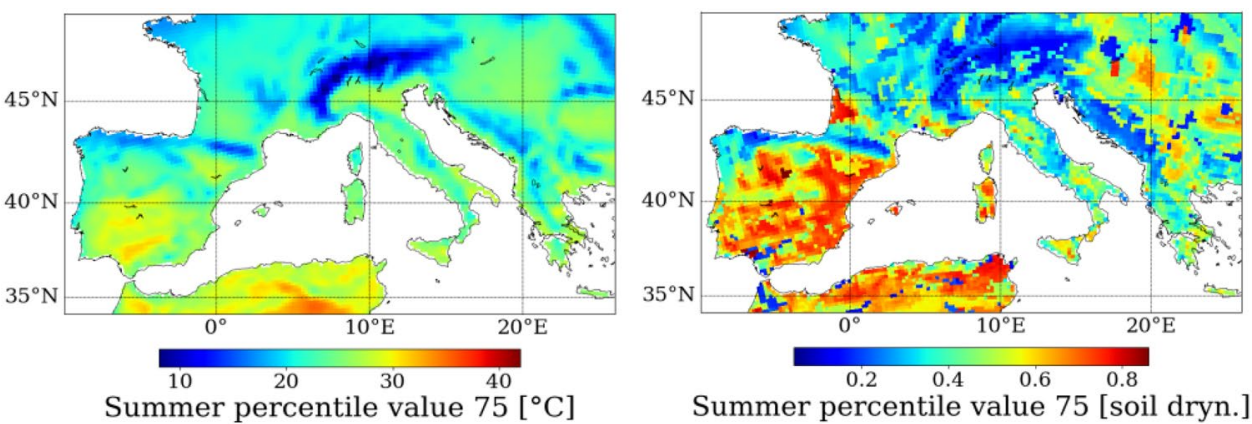

Summer percentile value 75 [soil dryn.]
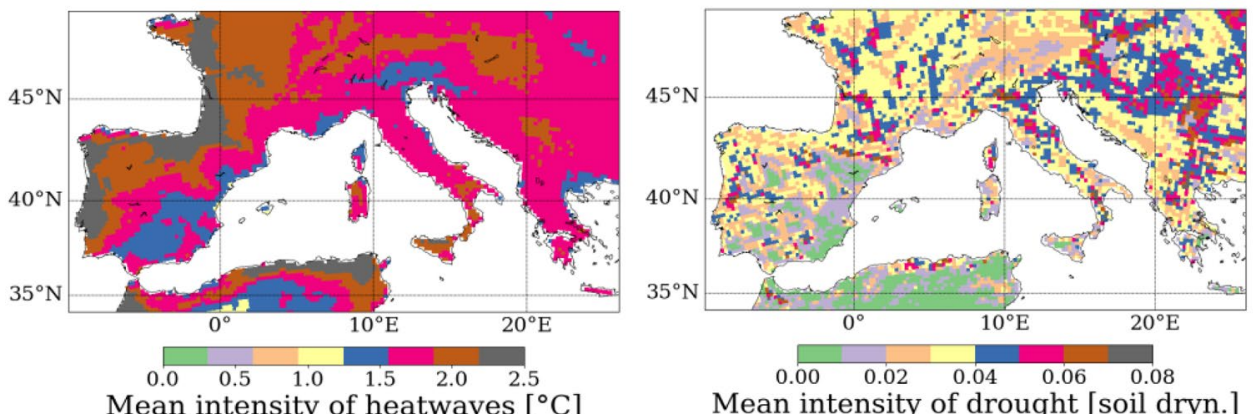

Mean intensity of heatwaves $\left[{ }^{\circ} \mathrm{C}\right]$

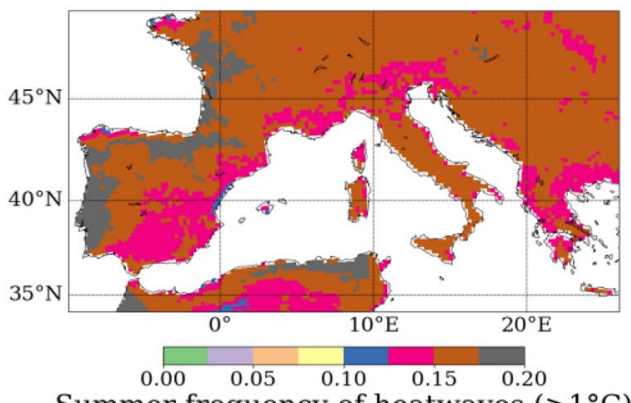

Mean intensity of drought [soil dryn.]

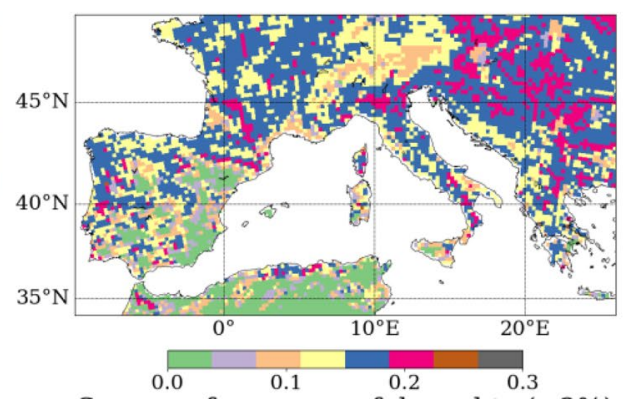

Summer frequency of droughts $(>2 \%)$

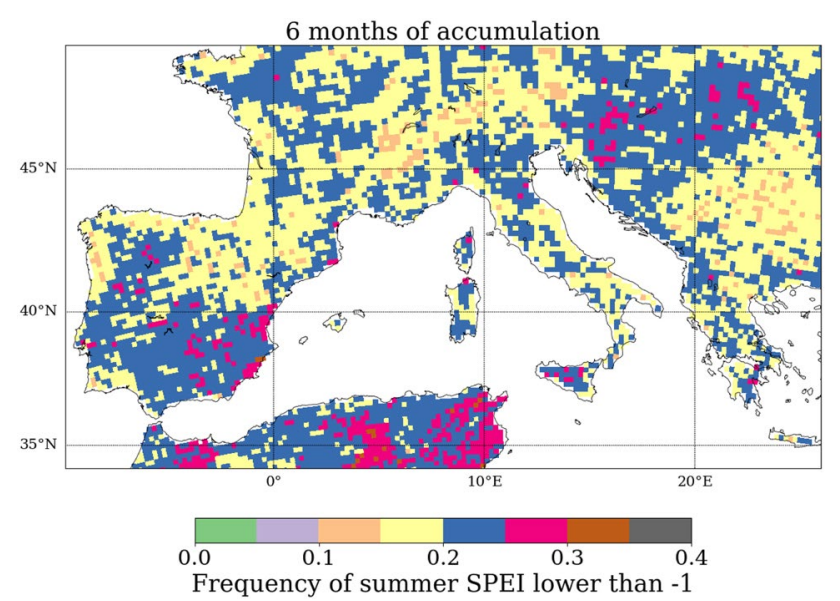

Fig. 5 Spatial distribution of frequency of summer SPEI lower than - 1 computed with 6 months of accumulation period. The frequency is expressed over the total number of summer months along the simulation period, namely 114 months
On the opposite side, semi-arid biomes can be affected by 1 -year-long droughts.

Raymond et al. (2016) also highlighted the Pannonian Plain as a cluster of drought occurrence. From 1957 to 2013, they identified 11 Very Long Dry Spells (designation for meteorological droughts based on wet season precipitation) with a mean duration of 62 day events. We found a good agreement on the periods identified.

The synoptic scale circulation in winter can cause a lack of precipitation and lead to the development of spring and summer droughts in the Euro-Mediterranean region. Raymond et al. (2018) showed that the Blocking regime and the Atlantic Ridge can lead to long winter dry spells in the Mediterranean (and especially in the East) through the subsidence of cold and dry air coming from higher latitudes. Moreover, years with the winter positive phase of the North Atlantic Oscillation (NAO), inducing drier and colder winters than normal over the Mediterranean, can lead to dry springs and summers (Trigo et al. 2004; Bladé et al. 2012; Raymond et al. 2018). We found a good agreement between positive values of the winter NAO index (Jones et al. 1997) 
and negative SPEI at the Western Mediterranean scale (not shown).

\subsection{Temporal variability}

The temporal variability of seasonal droughts and heatwaves identified for the sub-regions defined in Fig. 1 are provided in Fig. $6 \& 19$ (SM). Over the set of sub-regions, heatwaves occur almost every summer ( $97 \%$ of summers) due to the low percentile value chosen for this study (0.75). Heatwaves affect $80 \%$ of summers considering the percentile of 0.85 . Most of the spring and summer heatwaves are in the same range of intensity (between +1.0 and $+3.0^{\circ} \mathrm{C}$ ). The summer of 2003 is the season with the highest fraction of days marked as a heatwave for Southern Spain (0.46 during the period analyzed), Southern Italy (0.60) and Southern France (0.74). This record-breaking heatwave has been analyzed in numerous studies for its exceptional severity in Central Europe (e.g. Stéfanon et al. 2012b; Russo et al. 2015). The average duration of summer heatwaves is estimated to 5.8 days.

Compared to heatwaves, droughts are less frequent. 33\% of summers are affected by at least one drought event. The sub-regions Balkans, Maghreb, Southern Italy, Southern France and Western Iberian Peninsula are characterized by two clusters of intense summer droughts occurring at the beginning of the 1990s and 2000s. The average duration of summer droughts is 22.3 days.

The temporal distribution of spring (MAM) and summer (JJA) droughts are similar as they both depend on the variability of precipitation during the wet season (Fig. 6). On average, $90 \%$ of summer droughts are preceded by spring droughts. This shows the influence of spring precipitation and the temporal memory of the soil dryness for summer drought development (Vicente-Serrano et al. 2013). However, $23 \%$ of spring droughts are not followed by summer droughts, as in 1989, 1992, and 2008 for the entire Western Mediterranean domain. This is due to periods of heavier rainfall in early summer (June-July) which can compensate for a water deficit. Spring droughts (between +3 and $+8 \%$ ) are generally more intense than summer droughts (between +2 and $+5 \%$ ) according to the $P L A_{S D}$ method. The interannual variability (and so extremes above the percentile) of precipitation is higher in spring than in summer.

The variation of the SPEI, also shown in Fig. 6, is in good agreement with the $P L A_{S D}$ variation. Apart from few exceptions due to methodological differences (previously explained), positive anomalies of soil dryness from the 75th percentile are identified when SPEI values are lower than -1 . The major drought periods identified are similar to reports from the literature in the Mediterranean region (e.g. Hoerling et al. 2012; Spinoni et al. 2015).
Droughts and heatwaves occurring simultaneously were also identified. On average over the set of sub-regions, 32.6\% of dry days were also in a heatwave. The temporal correlation between $P L A_{S D}$ and $P L A_{T 2 m}$ can be considerable, especially in the northern Mediterranean, as shown in Fig. 20 of the supplementary material (e.g. coefficients of 0.4 and 0.5 over Southern France and the Balkans). With a mean increase of $18.5 \%$, heatwaves are significantly more intense for Southern France, Southern Spain, and the Maghreb when they are accompanied by droughts $\left(+2.3{ }^{\circ} \mathrm{C}\right.$ above the 75 th percentile in comparison to $+1.9^{\circ} \mathrm{C}$ ). This highlights the importance of the soil moisture-temperature feedback system in heatwave severity. Droughts are also more intense (6.9\%) when they occur simultaneously with heatwaves. However, the effect is non-significant, possibly because of the small sample size of droughts occurring alone.

\section{Isolated and combined effects of droughts and heatwaves}

\subsection{Leaf Area Index}

\subsubsection{LAI variations during droughts}

The impact of droughts on vegetation is first assessed by comparing the LAI observed for different summers, chosen to represent different conditions: 2010, which was wetter than the 1979-2016 average, and 2012, which was drier on average over the study area $\left(P L A_{S D}\right.$ of $\sim+4 \%$ at the Western Mediterranean scale). Figure 7 shows the comparison $\left(\Delta L A I=L A I_{2012}-L A I_{2010}\right)$ for the MODIS observations and the Med-CORDEX simulation (scaled to the MODIS amplitude), as well as the difference in PLA $_{S D}$ between both years (i.e. shift towards dry conditions), $\Delta$ PLA $_{S D}$. The patterns of positive difference in $\triangle$ PLA $_{S D}$ correspond to those of negative $\Delta \mathrm{LAI}$ for both MODIS and Med-CORDEX, showing that water stress leads to plant activity decline and biomass decrease. The LAI reduction in 2012 compared to 2010 can reach -1 unit over some areas (e.g. Central Spain). Conversely, areas of negative $\Delta \mathrm{PLA}_{S D}$ have positive $\Delta \mathrm{LAI}$.

Even if the $\triangle \mathrm{LAI}$ from MODIS and Med-CORDEX have similar spatial distributions, differences can be more heterogeneous in the MODIS data, and lower (e.g. Po valley), although the dynamical range of the RegIPSL LAI summer values has been normalized to that of MODIS. This may be explained by the fact that RegIPSL does not account for land use management while the reconstructed LAI from MODIS observations captures possible human effects. The impact of drought on LAI could be reduced by water supply from human intervention (irrigation). The Ebro valley and the Lombardia region are the largest irrigated cropland areas of the Western Mediterranean, according to the land 
Fig. 6 Temporal variation of spring (MAM) and summer (JJA) agricultural droughts for the sub-regions defined in Fig. 1 using the $P L A_{S D}$ method (on soil dryness). Left column: fraction of days affected. Right column: mean $P L A_{S D}$ and SPEI (intensity)
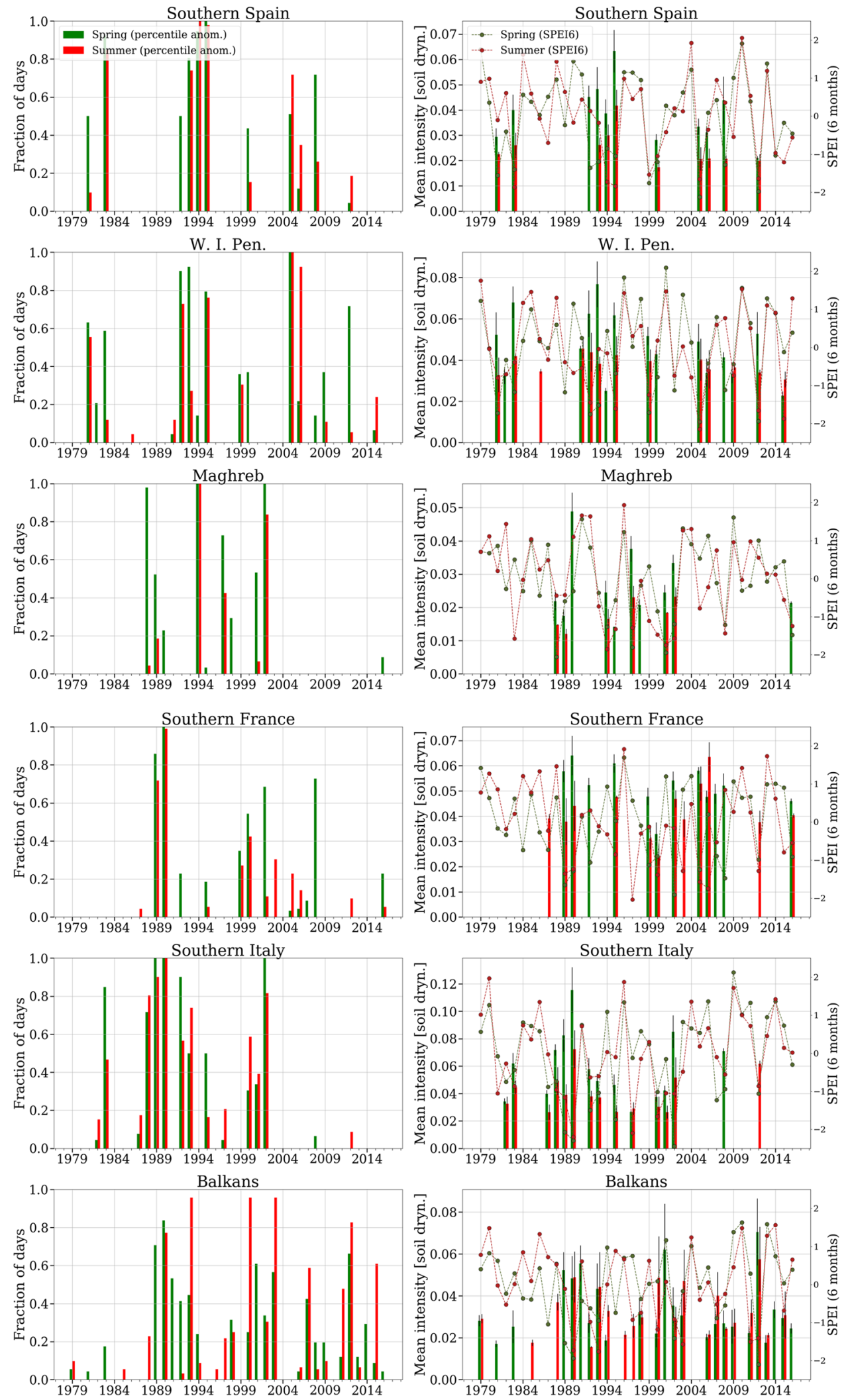

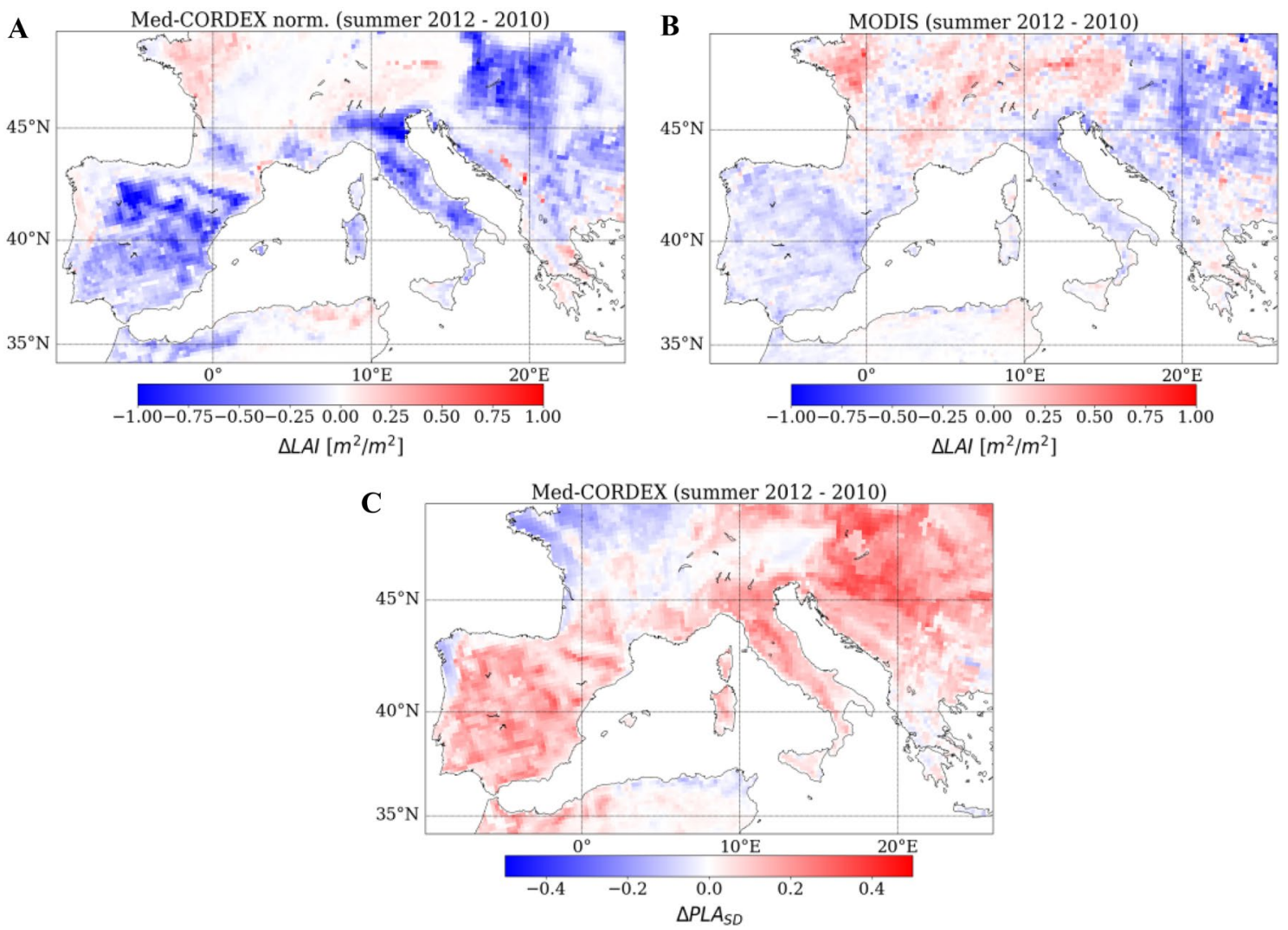

Fig. 7 Spatial distribution of mean $\triangle$ LAI between the summer of 2012 and 2010 with the Med-CORDEX simulation normalized (A) and MODIS observations (B). Spatial distribution of the mean $\triangle$ PLA $_{S D}$ with the Med-CORDEX simulation $(\mathbf{C})$

cover classification from the European Space Agency (ESA 2017). Considering an area of $10000 \mathrm{~km}^{2}$ located close to the outlet of the Ebro catchment area (southeastern part: $\left.\sim 42.0^{\circ} \mathrm{N}-0.1^{\circ} \mathrm{W}\right)$, MODIS LAI remains constant $(0.64)$ during the entire wet summer of 2010 while the simulated LAI endures a seasonal decrease (continuous from 1.09 to 0.60 ). During the extreme dry summer of 2012, the MODIS LAI is slightly below $2010(0.58)$ but remains constant during the entire summer suggesting that it is not affected by a water deficit. On the contrary, the simulated LAI decreases steeply as early as June (from 0.89 to 0.50 ) and the LAI remains low until the end of August.

The same analysis was performed for all dry years detected using the $P L A_{S D}$ method. Table 1 compares the observed and simulated summer $\Delta \mathrm{LAI}$ averaged over the sub-regions for a reference wet summer (2010) and the dry summers (2005, 2006 and 2012). The spring drought of 2008 , which was not followed by a summer drought, is also included. The $\Delta \mathrm{LAI}$ was also calculated relative to another reference summer, 2007, which was close to normal conditions, neither wet nor dry. The results obtained are similar to those presented here, which are only for sub-regions that experienced more than $10 \%$ of dry days during the selected summers.
Observed and simulated $\Delta \mathrm{LAI}$ are negative for all subregions, except the simulated "Balkans 2008". Within each sub-region, the difference in magnitude of $\Delta \mathrm{LAI}$ between the years is linked with drought severity. The largest $\Delta \mathrm{LAI}$ occurs in "Southern Spain 2005" with a value of - 23\% observed and $-33 \%$ simulated caused by the longest drought ( $48 \%$ of dry days during the summer). "Balkans 2012" is not characterized by a high decrease of LAI (about - 7\%) whereas $45 \%$ of its summer days were in drought conditions. This further highlights a specific behaviour in this elevated and forested region.

The spring drought of 2008 led to a decrease in LAI that continued into the summer despite normal weather conditions ( $-6 \%$ observed and $-16 \%$ simulated $\Delta \mathrm{LAI}$ over the western Mediterranean).

The observed $\Delta \mathrm{LAI}$ is generally smaller than the simulated variation (both in absolute and relative values). We have shown that water supply by irrigation can explain part of the differences. The type of biome is also important. The largest discrepancies between observed and simulated $\Delta \mathrm{LAI}$ occur in Southern Spain (semi-arid biomes) with $19 \%$ of difference in the summer of 2006. Maghreb presents also considerable differences (e.g. 2005 with 5\%) where the dominant PFT is bare soil. As already mentioned, MODIS is less 
Table 1 Mean $\triangle \mathrm{LAI}$ in absolute and relative values between the reference wet summer (2010) and the dry summers (2005, 2006 and 2015)/spring (2008) at the Western Mediterranean scale for Med-CORDEX simulation (weighted sum of PFTs) and MODIS observations

\begin{tabular}{|c|c|c|c|c|c|}
\hline & $\begin{array}{l}\Delta \text { LAI obs. } \\
\left(\mathrm{m}^{2} / \mathrm{m}^{2}\right)\end{array}$ & $\begin{array}{l}\Delta \text { LAI sim. } \\
\left(\mathrm{m}^{2} / \mathrm{m}^{2}\right)\end{array}$ & $\begin{array}{l}\text { Dry days } \\
(\%)\end{array}$ & $\begin{array}{l}\text { Simult. hot } \\
\text { days } \\
(\%)\end{array}$ & $\begin{array}{l}\text { Dominant } \\
\text { PFT }\end{array}$ \\
\hline Balkans 2008 & $-0.04(-2 \%)$ & $0.04(2 \%)$ & 16 & 4 & C3 agriculture \\
\hline Balkans 2012 & $-0.16(-7 \%)$ & $-0.14(-7 \%)$ & 45 & 25 & C3 agriculture \\
\hline Maghreb 2005 & $-0.04(-14 \%)$ & $-0.12(-19 \%)$ & 16 & 5 & Bare soil \\
\hline Maghreb 2008 & $-0.04(-13 \%)$ & $-0.09(-14 \%)$ & 15 & 3 & Bare soil \\
\hline Maghreb 2012 & $-0.01(-3 \%)$ & $-0.04(-7 \%)$ & 10 & 6 & Bare soil \\
\hline W. I. Pen. 2005 & $-0.22(-16 \%)$ & $-0.20(-15 \%)$ & 37 & 14 & $\mathrm{C} 3$ agriculture \\
\hline W. I. Pen. 2006 & $-0.15(-11 \%)$ & $-0.24(-17 \%)$ & 31 & 11 & C3 agriculture \\
\hline W. I. Pen. 2008 & $-0.03(-3 \%)$ & $-0.05(-6 \%)$ & 10 & 2 & C3 grass \\
\hline W. I. Pen. 2012 & $-0.10(-7 \%)$ & $-0.14(-11 \%)$ & 19 & 4 & C3 agriculture \\
\hline S. France 2005 & $-0.13(-7 \%)$ & $-0.21(-12 \%)$ & 13 & 4 & C3 agriculture \\
\hline S. France 2006 & $-0.21(-11 \%)$ & $-0.38(-20 \%)$ & 12 & 7 & C3 agriculture \\
\hline S. France 2012 & $-0.04(-2 \%)$ & $-0.16(-10 \%)$ & 10 & 4 & C3 agriculture \\
\hline S. Italy 2012 & $-0.11(-6 \%)$ & $-0.27(-14 \%)$ & 11 & 6 & C3 agriculture \\
\hline S. Spain 2005 & $-0.17(-23 \%)$ & $-0.35(-33 \%)$ & 48 & 15 & C3 agriculture \\
\hline S. Spain 2006 & $-0.11(-15 \%)$ & $-0.37(-34 \%)$ & 34 & 11 & C3 grass \\
\hline S. Spain 2008 & $-0.04(-6 \%)$ & $-0.20(-21 \%)$ & 38 & 7 & C3 grass \\
\hline S. Spain 2012 & $-0.14(-18 \%)$ & $-0.37(-32 \%)$ & 35 & 12 & C3 agriculture \\
\hline W. Medit. 2005 & $-0.14(-11 \%)$ & $-0.24(-17 \%)$ & 25 & 8 & C3 agriculture \\
\hline W. Medit. 2006 & $-0.14(-9 \%)$ & $-0.31(-19 \%)$ & 19 & 8 & C3 agriculture \\
\hline W. Medit. 2008 & $-0.05(-6 \%)$ & $-0.18(-16 \%)$ & 13 & 3 & C3 grass \\
\hline W. Medit. 2012 & $-0.11(-8 \%)$ & $-0.27(-17 \%)$ & 20 & 8 & $\mathrm{C} 3$ grass \\
\hline
\end{tabular}

$\Delta \mathrm{LAI}$ is computed only for drought days. The percentage of dry days and simultaneous hot days for the considered summer is given in the fourth and fifth column. Only years with at least $10 \%$ of summer dry days are kept. The dominant PFT affected is given in the last column efficient for identifying drought effects on sparse vegetation (Chakroun et al. 2014). Results for these regions may therefore be less reliable. In other sub-regions, C3 agriculture and grass are the dominant PFTs affected.

The temporal correlation between daily LAI anomalies and PLA ${ }_{S D}$ during the summer is mapped on Fig. 8 based on the observations and Fig. 9 based on the simulation. For MODIS, negative and significant correlations, ranging from -0.5 to -0.9 , are obtained over almost the entire Western
Mediterranean except the mountainous areas (e.g. Pyrenees). These areas are much less soil moisture limited (due to higher precipitation and lower evaporative demand). The simulated LAI (all PFTs) shows similar patterns. However, opposite correlations are obtained for the simulated LAI in the Western France, which may be explained by irrigated croplands not accounted for.

The effect of droughts on plant growth is expected to be very dependant on vegetation type and biome (e.g.

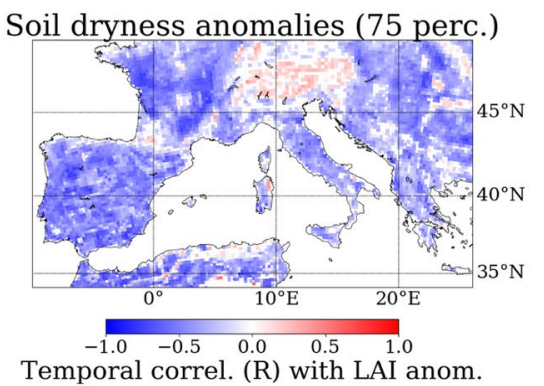

Fig. 8 Spatial distribution of temporal correlation (R) during summers (2003-2016) between MODIS LAI anomalies and $P L A_{S D}$ (left), $P L A_{T 2 m}$ (middle) and combined $P L A_{S D, T}$ (right). White cells correspond to non-significant correlation coefficients (Spearman
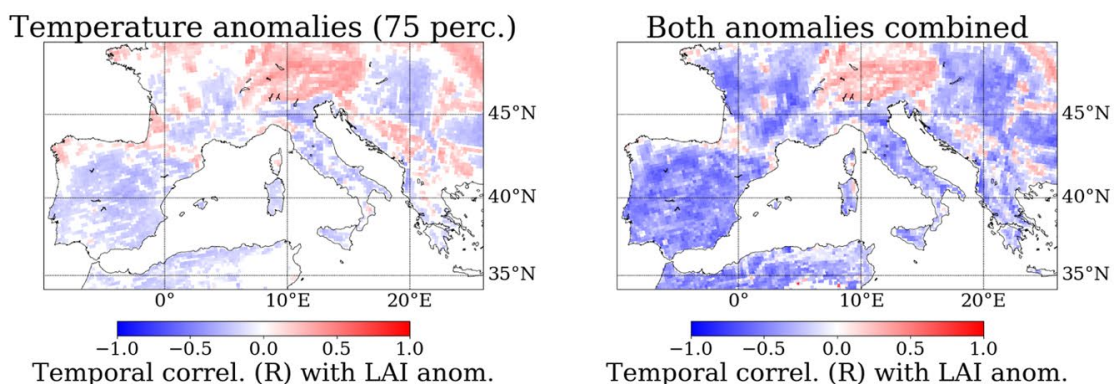

Temporal correl. (R) with LAI anom. test p-value $>0.1$ ). Each summer includes 24 days of observations (4 days average for the LAI), so that the final time series contain 336 values 

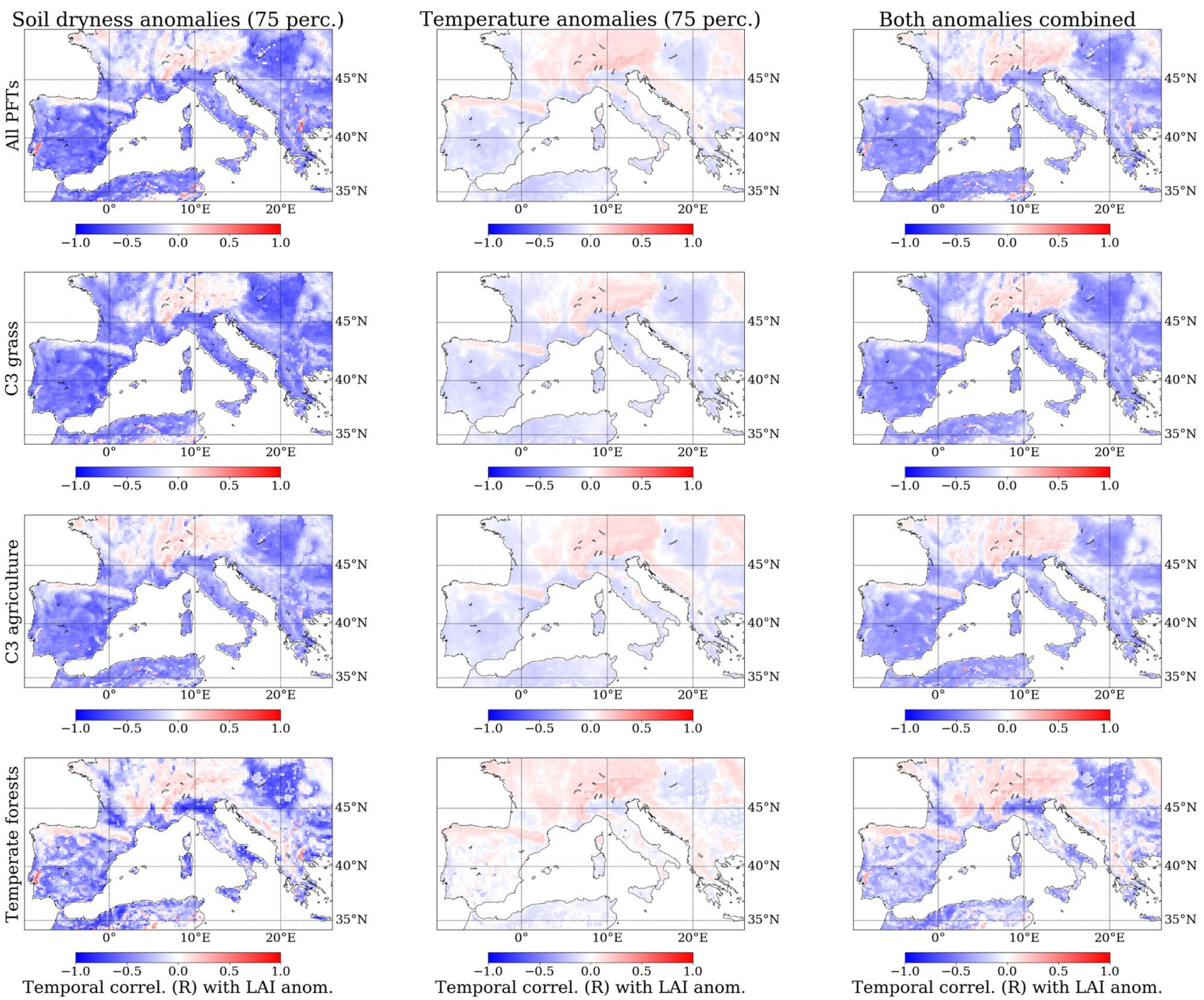

Fig. 9 Spatial distribution of temporal correlation (R) during summers (1979-2016 period) between Med-CORDEX LAI anomalies and $P L A_{S D}$ (left), $P L A_{T 2 m}$ (middle) and combined $P L A_{S D, T}$ (right).

Vicente-Serrano 2007; Gouveia et al. 2017). To discuss this, the correlation between simulated LAI anomalies and $P L A_{S D}$ is calculated for each PFT and each summer month of the period 1979-2016 (not shown), as well as for the full summer (June-July-August) as shown on Fig. 9. C3 grass and agriculture are highly correlated with $P L A_{S D}$ from June until August (between -0.5 and -0.9 depending on the sub-region). Plants with shallow root systems are sensitive to water shortages as soon as the early summer. On the opposite side, correlations for forests are low in June $(\sim-0.1)$ and increase during the season ( -0.7 in August). Forests have longer resistance to droughts than grassland and agriculture due to their deeper root systems. In addition, the semi-arid biomes (Northern Africa and Andalusia) show a strong negative correlation throughout the summer. This
White cells correspond to non-significant correlation coefficients (Spearman test $\mathrm{p}$-value $>0.1$ ). Each row represents a selection of PFT

type of biome may be exposed to a significant decrease in biomass from early to late summer, with possible plant mortality (Vicente-Serrano et al. 2013).

\subsubsection{LAI variations during heatwaves}

Following the same method as with droughts, the LAI anomalies during heatwaves have been computed (SM: Table 2). The variation of LAI is computed as the difference between LAI during summer heatwaves not accompanied by durable droughts (2003, 2009, 2011 and 2016) and a reference summer without heatwaves (2014). The LAI decrease is considerably lower during heatwaves than during droughts, and sometimes even close to 0 (e.g. Southern Spain). Heatwaves can cause an effect reaching up to $-10 \%$ (for MODIS and 
Med-CORDEX). The intense summer heatwave of 2003 induced a LAI decrease of $\sim 14 \%$ in Southern Italy. This record-breaking heatwave affected also sub-regions located further north: $\sim-8 \%$ of LAI in the Balkans and $\sim-12 \%$ in Southern France.

The correlation between $P L A_{T 2 m}$ and LAI anomalies during summers from MODIS (resp. from Med-CORDEX) are shown in Fig. 8 (resp. Fig. 9). They do not show a strong signal of co-variance. Correlations with MODIS LAI are overall slightly negative (between -0.2 and -0.4 with some non-significant values) but positive over the Northern Mediterranean, as well as the mountainous areas. The spatial distribution of correlation values with Med-CORDEX LAI is very similar, however, slightly lower (between -0.1 and $-0.3)$.

\subsubsection{Combined effect of droughts and heatwaves on LAI}

Summer droughts are often characterized by simultaneous heatwaves of varying intensity: from $4 \%$ of summer days for "Western Iberian Peninsula 2012" to 25\% for "Balkans 2005" (see Table 1 as example).

The $\Delta \mathrm{LAI}$ induced by droughts without heatwaves is similar to all droughts (with or without heatwaves) in all sub-regions. On average over the Western Mediterranean, the mean LAI decrease during droughts alone is reduced by $0.01 \mathrm{~m}^{2} / \mathrm{m}^{2}$ compared to the $\Delta \mathrm{LAI}$ for all droughts, whereas the number of dry days decreases by $8 \%$. According to our results, a simultaneous heatwave during a drought does not induce cumulative biomass reduction and can even counterbalance the effect of the drought (e.g. Northern Mediterranean).

The synergetic effect of droughts and heatwaves is further characterised using correlations between LAI and $P L A_{S D, T}$ (right panels of Figs. 8 and 9). It is less anti-correlated with LAI than $P L A_{S D}$ because the higher temperature can have a compensating effect (mean difference of correlation of 0.08 for observed LAI and 0.10 for simulated LAI). Being combined, opposite signals of droughts and heatwaves, such as in the Balkans, can lead to an absence of correlation with LAI anomalies.

\subsection{Fire activity}

\subsubsection{Effect of heatwaves, droughts and wind gusts on large fires}

The spatial and temporal distribution of wildfires is highly variable. We analyzed the impact of isolated and combined extreme weather events with clustering: wind gust, heatwave, drought and normal conditions (no heatwave nor drought). Figure 10 presents the distribution of large fire characteristics (as defined in Sect. 2.3), for each cluster over the Western Mediterranean. The number of large fires varies considerably between clusters. The largest number of fires is found in the cluster "heatwave" with 509 events, highlighting the prevalent role of hot temperatures. 103 and 107 large fires occur, respectively, during droughts and wind gusts over the 2003-2016 period.

Compared to wildfires occurring during normal conditions (median FD of 4.0 days, BA of $3.6 \mathrm{~km}^{2}$, and FRP of $102 \mathrm{MW}$ ), all the fire characteristics are significantly higher during agricultural droughts, heatwaves, or wind gusts (Mann Whitney U test p-value $<0.01$ ). The three clusters have similar median distributions of FD (5 days). However, limiting the water availability for plants, agricultural droughts lead to a considerably larger median BA $\left(7.1 \mathrm{~km}^{2}\right)$ and FRP (225 MW) than heatwaves (significant difference of $+1.2 \mathrm{~km}^{2}$ and $+84 \mathrm{MW}$ ) and wind gusts (non significant difference of $+0.9 \mathrm{~km}^{2}$ and $+33 \mathrm{MW}$ ). Those meteorological and hydrological conditions are major controlling factors of fire intensity and propagation over the Western Mediterranean. Hot and dry atmospheric conditions enhance the flammability with fire ignition and spread more likely to happen (Sarris et al. 2014). Agricultural droughts also decrease the fuel moisture (Turco et al. 2017). Strong winds also boost biomass burning, even with "cold" winds (Hernandez et al. 2015; Duane and Brotons 2018).

The cluster analysis was also conducted for isolated and combined extreme events (Fig. 10). During wind gusts, the meteorological conditions can be very different from agricultural droughts and heatwaves, especially at the Western Mediterranean scale. The combined effects of heatwaves and/or droughts with wind gusts could not be analyzed due to the low number of fire events in this cluster (non significant results). Subsequently, the effects of droughts and heatwaves are studied independently of wind. The highest median BA $\left(8.0 \mathrm{~km}^{2}\right)$ and FD (6.0 days) observed occur in the cluster of isolated droughts ("dr. and not hw." with only 43 large fires). Nevertheless, simultaneous droughts and heatwaves (cluster "hw. and dr.", 60 large fires) induce fire characteristics larger than each individual cluster ("heatwave" and "drought"): median BA of $7.5 \mathrm{~km}^{2}$, FRP of $293 \mathrm{MW}$, and FD of 5.5 days, which represent, respectively, a multiplication factor of 2.1, 2.9 , and 1.4 compared to normal conditions. These results suggest that their respective effects can be cumulative.

\subsubsection{Impact of meteorological conditions or fuel availability}

The cluster analysis showed that extremely dry and hot weather conditions exacerbate summer wildfire activity. However, the fire intensity could be limited by a reduced fuel availability following a dry pre-fire season. The relative importance of each of these factors has been then explored using correlation analysis. 
Fig. 10 Summer Burned Area (bottom panel on log scale), Fire Radiative Power (middle pannel), and Fire Duration (top pannel), observed by the MODIS satellite instrument during isolated and combined extreme events over the Western Mediterranean, represented by individual boxplots. From left to right are the clusters using the PLA method: "windspells", "heatwaves", "droughts", "no heatwave nor drought", "heatwaves or droughts", "simultaneous droughts and heatwaves", "heatwaves without droughts" and "droughts without heatwaves". Only fire lasting more than 1 day and burning more than $1 \mathrm{~km}^{2}$ are kept. Fires next to each other, and separated by 2 days, are grouped into the same fire event. The number of fire events is between the parentheses. The red squares are the mean of the distribution and the black circles are the outliers. The box covers the InterQuartile Range (IQR) between Q1 (25th percentile) and Q3 (75th percentile). The lower whisker is limited to a statistical minimum (Q1 - 1.5*IQR) and the upper one to a statistical maximum $(\mathrm{Q} 3+1.5 * \mathrm{IQR})$
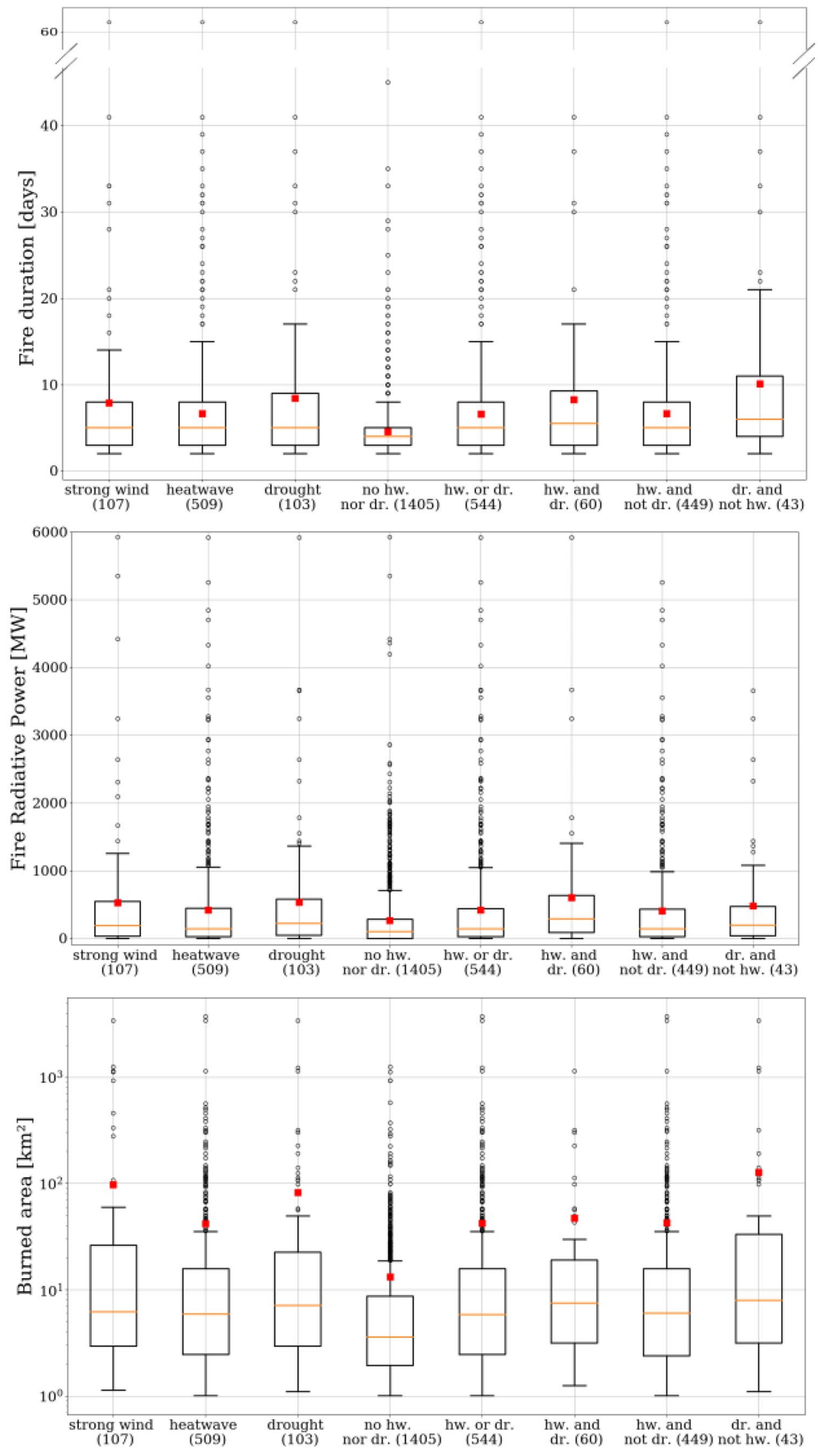


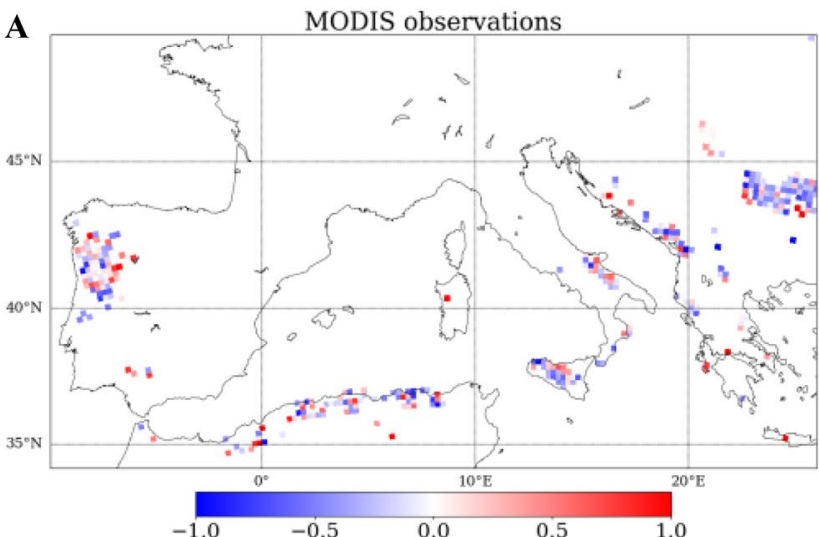

Temporal correlation (R) between the summer FRP and LAI

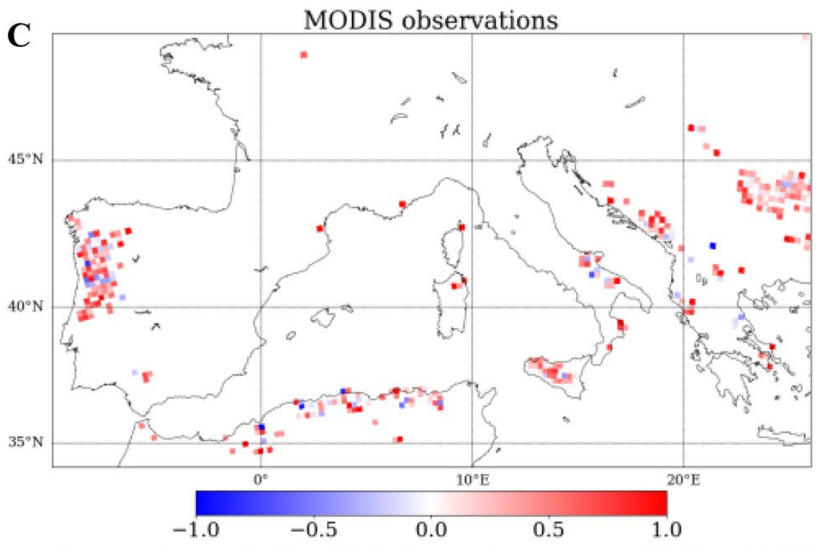

Temporal correlation (R) between the summer FRP and CDI

Fig. 11 Spatial distribution of temporal correlation (R) between summer Fire Radiative Power (FRP) and Leaf Area Index (LAI) from MODIS (A) and from Med-CORDEX (B) for areas of high fire activity (pixels with at least $1 \mathrm{~km}^{2}$ of burned area for minimum 3 summers over 2003-2016). Same criteria of correlation are applied

Figure $11 \mathrm{~A}$ and $\mathrm{B}$ map the temporal correlations between the daily FRP (for large fires) and LAI from MODIS and Med-CORDEX during the summers of 2003-2016. The same analysis has been performed with the BA (not shown) and similar results were obtained. Since $90 \%$ of summer droughts are preceded by spring (MAM) droughts (see Sect. 5.2), the summer LAI metric includes the temporal memory of the soil dryness from the pre-fire season. Negative correlations mean that even with a decrease of the summer biomass density from one year to another due to an agricultural drought during the preceding spring, the summer FRP increases. On the contrary, positive correlations mean that FRP variations are driven by fuel availability.

Our results do not show a single major signal. For simulated and observed LAI, FRP-LAI correlations are significantly negative or positive for several sub-regions (Western Iberian Peninsula, Maghreb, Southern Italy, and Balkans).

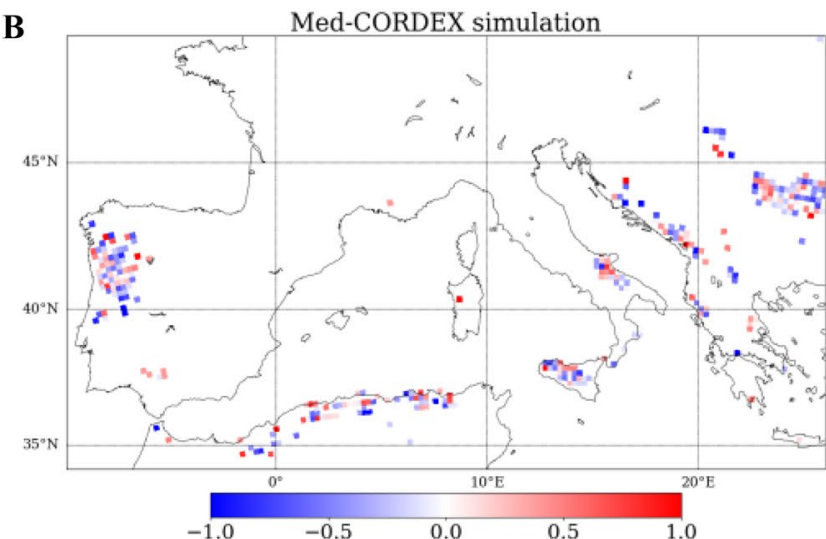

Temporal correlation (R) between the summer FRP and LAI

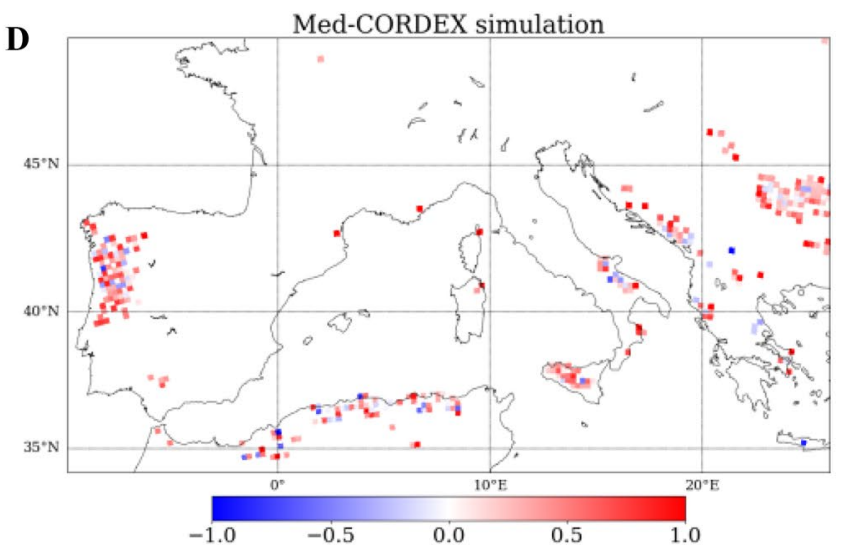

Temporal correlation (R) between the summer FRP and CDI

between FRP and CDI from MODIS (C) and from Med-CORDEX (D). Number of hot days (NHD) used for CDI is from Med-CORDEX $\left(P L A_{T 2 m}\right)$ in both configurations. Only significant correlation (Spearman test with p-value $<0.1$ ) are shown

In summary, the fuel driver does not explain the inter-annual variability in a fully consistent way.

The correlations between the fire characteristics and the hydrological and meteorological conditions, using the Number of Dry Days (NDD) and Hot Days (NHD), have also been studied. Positive correlations are obtained all over the Western Mediterranean ( $\mathrm{R}$ values between 0.5 and 0.9 ) (see SM Sect. 8). Correlations are higher with NDD, as we showed that droughts induce a larger enhancement of fire activity than heatwaves (see Fig. 10). However, NDD-FRP correlations are not significant in the Maghreb sub-region. Turco et al. (2017) show that the relationship between droughts and fire activity could be stronger in the Northern Mediterranean, where soil is initially wetter and vegetation more active than in the Southern Mediterranean, with semiarid biomes.

The synergetic effect of meteorological conditions and fuel load are integrated in the Climate Driver Index, initially 
developed by Gouveia et al. (2016). Here, it is defined as the ratio between the NHD and the summer average LAI:

$$
C D I=\frac{N H D}{L A I}
$$

In order to evaluate if the fire regime is led by the climate driver (favourable warm and dry weather conditions) or the fuel driver (favourable biomass availability), the temporal correlation between the CDI and the FRP (as well as the BA) is analyzed (Fig. 11C and D). The correlation is significantly positive ( $r$ values between 0.5 and 0.8 ) almost over all of the Western Mediterranean, suggesting that the pluri-annual fire regime is led by the climate driver. Short-term effects of favourable weather conditions for fire ignition and spread are sufficiently strong enough to dominate the longer effect of biomass availability.

Analyzing the fire season of 2007 in Southern Greece (Peloponnese Peninsula) which was characterized by two summer heatwaves and a drought, Gouveia et al. (2016) found that higher fire activity was located in areas of high accumulated precipitation (during September 2006 and August 2007). They suggested that large burned areas within the affected region can be more sensitive to vegetation density than to weather conditions. Considering the same study area and period, we also observed that fires with the highest BA $\left(>80 \mathrm{~km}^{2}\right)$ occurred in areas of slightly positive anomalies of LAI from MODIS, for June (+ 0.1 in comparison to the 2003-2016 period) (not shown). However, we did not find any significant correlation over Southern Greece on the basis of our regional pluri-annual analysis.

\section{Summary and conclusions}

The objective of this study is to quantify the isolated and combined impacts of heatwaves and droughts on vegetation and wildfires, using extreme events identified based on regional land surface-atmospheric modeling and impacts observed by satellite observations of surface properties (MODIS). The comparison of RegIPSL key, simulated variables, with observations, demonstrates that the model is appropriate for research on droughts and heatwaves. While simulated summer mean $2 \mathrm{~m}$ temperature and rainfall from Med-CORDEX show a constant daily overestimation compared to E-OBS, they are within its range of standard error. Extreme conditions are well represented. Two methods have been used to identify extreme events: the SPEI for meteorological droughts, the Percentile Limit Anomalies (PLA) on the $2 \mathrm{~m}$ temperature for heatwaves, on the soil dryness for agricultural droughts, and on surface winds for strong wind events (the latter used for wildfire regimes only). Even if the temporal variability of major droughts detected using the SPEI is close to those detected using the $P L A_{S D}$, differences remain in their spatial distribution. Besides the weather conditions, the $P L A_{S D}$ method accounts for local heterogeneities of soil and vegetation type in the variability of the soil water content. Moreover, SPEI estimates the evapotranspiration from temperature, whereas the limiting factor in semi-arid biomes is often the soil water availability. The SPEI is relevant for detecting meteorological droughts, and the $P L A_{S D}$ method is more suitable for detecting agricultural droughts, as well as analyzing their impact on plant biomass and fire behavior.

Heatwaves identified based on the E-OBS observations are slightly less intense than those identified based on the Med-CORDEX simulation (maximum difference of $-0.5^{\circ}$ C); they show similar variability. Moreover, spatio-temporal patterns of both heatwaves and droughts are in good agreement with similar studies found in the scientific literature (e.g. Russo et al. 2015; Raymond et al. 2016). The most intense $\left(2{ }^{\circ} \mathrm{C}\right.$ above the 75 th percentile) and frequent $(17 \%$ of the summertime with $P L A_{T 2 m}>1{ }^{\circ} \mathrm{C}$ ) summer heatwaves occurred over the western part of the domain (Western Iberian Peninsula and Western France), Northern Africa, and the Pannonian Plain. The last is also affected by intense ( $+5 \%$ of soil dryness above the 75 th percentile) and frequent (20\% of the summertime with $P L A_{S D}>2 \%$ ) agricultural droughts. Even if agricultural droughts affect fewer summers (33\%) than heatwaves (97\%), they last almost four times longer (mean duration of 22.3 days versus 5.8 days). Moreover, $90 \%$ of summer droughts are preceded by spring droughts. This emphasizes how the temporal memory of weather conditions of the wet season determine agricultural drought development even during the summer season. We also highlighted the high co-variability between droughts and heatwaves over some areas (e.g. Balkans and Northern Italy). Heatwaves that occur at the same time as droughts are significantly more intense $(+18.5 \%$ on average).

Due to water stress, agricultural droughts lead to plant activity decline and a significant biomass decrease. This impact has been assessed using both observed and simulated LAI. We have shown that MODIS observations of LAI can capture some human effects that are not yet included in the simulations. Water supply by irrigation can reduce and even mask drought effects, as identified in the Ebro valley. Almost $30 \%$ of the croplands in the Mediterranean are irrigated, with the biggest areas in Spain, Northern Italy, and Morroco (Harmanny and Malek 2019). Moreover, the limited ability of MODIS to evaluate accurately the LAI in sparse canopies, such as in semi-arid biomes, has been highlighted by Sprintsin et al. (2009). However, the general response to heat and water stress is well simulated. Averaged over the Western Mediterranean, the LAI decrease between wet and dry summers is estimated at $-10.0 \%$ (from MODIS observations) with some critical areas reaching $-23 \%$, such as in Southern Spain (during the summer of 2005). The simulated 
decrease of LAI by Med-CORDEX is larger (-17.7\%), possibly because it does not include human irrigation. However, both LAI have similar spatial patterns of biomass variation. The drought effect on biomass variation depends on the plant and biome type. This effect is weaker on vegetation with a deep root system (e.g. temperate forests), as well as for elevated or temperate regions with water reserves more often filled up than in semi-arid biomes.

Summer heatwaves, through thermal stress, can lead to biomass decrease, but to a much smaller extent than droughts. Averaged over the Western Mediterranean, we computed a mean observed and simulated LAI decrease of, respectively, $3.0 \%$ and $3.7 \%$. We did not find significant cumulative effects of summer droughts and heatwaves on biomass reduction.

Heatwaves and droughts significantly promote summer wildfires. Through a synergistic effect, simultaneous droughts and heatwaves can worsen median BA by $3.9 \mathrm{~km}^{2}$, FRP by $341 \mathrm{MW}$, and FD by 1.5 days, compared to normal conditions (2.1, 2.9, and 1.4 times more, respectively). Heatwaves and agricultural droughts contribute to an increased wildfire severity. Moreover, deficits in soil water content can begin in the spring and induce a decrease of the potentially combustible fuel measured here with the LAI. Using the CDI (positively correlated to BA and FRP), we have shown that the inter-annual variation of fire activity is not limited by the fuel availability; favourable extreme weather conditions have a dominant effect.

In conclusion, even if agricultural droughts do not occur each summer, such extreme weather events can develop over long periods, inducing significant adverse effects on the biosphere. Firstly, persistent water stress leads to plant activity decline and biomass decrease. Secondly, droughts can worsen peaks of fire activity, mainly occurring during heatwaves. Isolated droughts are also favourable to intense fires.

This work provides, to the best of our knowledge, the longest spatio-temporal database of agricultural droughts over the Mediterranean using a coupled surface atmosphere model. The method used for the identification of extreme events (PLA method) allows drought and heatwave phenomena to be related. This approach will allow for a more complete assessment of the various impacts of these extreme events (e.g. mitigation and prevention programs about loss of agricultural yield or forest ecosystems), especially in the context of climate change, with the increasing temperature and decreasing precipitation over the Mediterranean region.

Supplementary Information The online version supplementary material available at https://doi.org/10.1007/s00382-021-05938-y.

Acknowledgements This work was granted access to the HPC resources of IDRIS under the allocation 2019-0227 attributed by GENCI (Grand Equipement National de Calcul Intensif). We acknowledge the E-OBS dataset from the EU-FP6 project UERRA (http://www.uerra.eu) and the data providers in the ECA\&D project (https://www.ecad.eu). The MODIS MCD64, MCD12 MOD14 and MCD153AH products were retrieved from the NASA EOSDIS Land Processes Distributed Active Archive Center (LPDAAC), USGS Earth Resources Observation and Science (EROS) Center, Sioux Falls, South Dakota (https://lpdaac.usgs.gov/data/). Finally, we acknowledge the contribution by Thomas Miraglio who performed a preliminary analysis during an internship in the team at LMD.

Open Access This article is licensed under a Creative Commons Attribution 4.0 International License, which permits use, sharing, adaptation, distribution and reproduction in any medium or format, as long as you give appropriate credit to the original author(s) and the source, provide a link to the Creative Commons licence, and indicate if changes were made. The images or other third party material in this article are included in the article's Creative Commons licence, unless indicated otherwise in a credit line to the material. If material is not included in the article's Creative Commons licence and your intended use is not permitted by statutory regulation or exceeds the permitted use, you will need to obtain permission directly from the copyright holder. To view a copy of this licence, visit http://creativecommons.org/licenses/by/4.0/.

\section{References}

Bastin S, Chiriaco M, Drobinski P (2018) Control of radiation and evaporation on temperature variability in a WRF regional climate simulation: comparison with colocated long term ground based observations near Paris. Clim Dyn 51(3):985-1003. https://doi. org/10.1007/s00382-016-2974-1

Baumbach L, Siegmund JF, Mittermeier M, Donner RV (2017) Impacts of temperature extremes on European vegetation during the growing season. J Geophys Res 14(21):4891-4903. https://doi.org/10. 5194/bg-14-4891-2017

Beer T (1991) The interaction of wind and fire. Boundary-Layer Meteorol 54(3):287-308

Bladé I, Liebmann B, Fortuny D, van Oldenborgh GJ (2012) Observed and simulated impacts of the summer NAO in Europe: implications for projected drying in the Mediterranean region. Clim Dyn 39(3-4):709-727. https://doi.org/10.1007/s00382-011-1195-x

Bowman DM, Balch JK, Artaxo P, Bond WJ, Carlson JM, Cochrane MA, D'Antonio CM, DeFries RS, Doyle JC, Harrison SP et al (2009) Fire in the earth system. Science 324(5926):481-484. https://doi.org/10.1126/science.1163886

Caldararu S, Purves D, Palmer P et al (2014) Phenology as a strategy for carbon optimality: a global model. J Geophys Res 11(3):763778. https://doi.org/10.5194/bg-11-763-2014

Cassou C, Terray L, Phillips AS (2005) Tropical Atlantic influence on European heat waves. J Clim 18(15):2805-2811. https://doi.org/ 10.1175/JCLI3506.1

Chakroun H, Mouillot F, Nasr Z, Nouri M, Ennajah A, Ourcival J (2014) Performance of LAI-MODIS and the influence on drought simulation in a Mediterranean forest. Ecohydrology 7(3):10141028. https://doi.org/10.1002/eco.1426

Chakroun M, Bastin S, Chiriaco M, Chepfer H (2018) Characterization of vertical cloud variability over Europe using spatial Lidar observations and regional simulation. Clim Dyn 51(3):813-835. https://doi.org/10.1007/s00382-016-3037-3

Cornes RC, van der Schrier G, van den Besselaar EJ, Jones PD (2018) An ensemble version of the E-OBS temperature and precipitation data sets. J Geophys Res 123(17):9391-9409. https://doi.org/10. 1029/2017JD028200 
Craig A, Valcke S, Coquart L (2017) Development and performance of a new version of the oasis coupler, OASIS3-MCT\_3. 0. Geosci Model Dev 10(9). https://doi.org/10.5194/gmd-10-3297-2017

De Rosnay P, Polcher J, Bruen M, Laval K (2002) Impact of a physically based soil water flow and soil-plant interaction representation for modeling large-scale land surface processes. J Geophys Res 107(D11):ACL-3. https://doi.org/10.1029/2001JD000634

Demarty J, Chevallier F, Friend A, Viovy N, Piao S, Ciais P (2007) Assimilation of global Modis leaf area index retrievals within a terrestrial biosphere model. Geophys Res Lett 34(15). https://doi. org/10.1029/2007GL030014

Di Luca A, Flaounas E, Drobinski P, Brossier CL (2014) The atmospheric component of the Mediterranean sea water budget in a WRF multi-physics ensemble and observations. Clim Dyn 43(910):2349-2375. https://doi.org/10.1007/s00382-014-2058-z

Drobinski P, Anav A, Brossier CL, Samson G, Stéfanon M, Bastin S, Baklouti M, Béranger K, Beuvier J, Bourdallé-Badie R et al (2012) Model of the regional coupled earth system (MORCE): application to process and climate studies in vulnerable regions. Environ Model Softw 35:1-18. https://doi.org/10.1016/j.envsoft. 2012.01.017

Drobinski P, Bastin S, Arsouze T, Beranger K, Flaounas E, Stefanon M (2018) North-western Mediterranean sea-breeze circulation in a regional climate system model. Clim Dyn 51(3):1077-1093. https://doi.org/10.1007/s00382-017-3595-z

Duane A, Brotons L (2018) Synoptic weather conditions and changing fire regimes in a Mediterranean environment. Agric Forest Meteorol 253:190-202. https://doi.org/10.1016/j.agrformet.2018. 02.014

ESA (2017) ESA CCI land cover time-series v2.0.7 (1992-2015). Report, European Space Agency-Climate Change Initiative. https://maps.elie.ucl.ac.be/CCI/viewer/

Fang H, Liang S, Hoogenboom G (2011) Integration of MODIS LAI and vegetation index products with the CSM-CERES-maize model for corn yield estimation. Int J Remote Sens 32(4):10391065. https://doi.org/10.1080/01431160903505310

Fischer EM, Seneviratne SI, Lüthi D, Schär C (2007) Contribution of land-atmosphere coupling to recent European summer heat waves. Geophys Res Lett 34(6). https://doi.org/10.1029/2006GL029068

Friedl MA, Sulla-Menashe D, Tan B, Schneider A, Ramankutty N, Sibley A, Huang X (2010) Modis collection 5 global land cover: algorithm refinements and characterization of new datasets. Remote Sens Environ 114(1):168-182. https://doi.org/10.1016/j. rse.2009.08.016

Giglio L, Csiszar I, Justice CO (2006) Global distribution and seasonality of active fires as observed with the terra and aqua moderate resolution imaging spectroradiometer (MODIS) sensors. J Geophys Res 111(G2). https://doi.org/10.1029/2005JG000142

Giglio L, Randerson J, Van der Werf G, Kasibhatla P, Collatz G, Morton D, DeFries R (2010) Assessing variability and long-term trends in burned area by merging multiple satellite fire products. J Geophys Res 7(3):1171-1186. https://doi.org/10.5194/ bg-7-1171-2010

Giglio L, Boschetti L, Roy DP, Humber ML, Justice CO (2018) The collection 6 MODIS burned area mapping algorithm and product. Remote Sens Environ 217:72-85. https://doi.org/10.1016/j. rse.2018.08.005

Gouveia CM, Bistinas I, Liberato ML, Bastos A, Koutsias N, Trigo $\mathrm{R}$ (2016) The outstanding synergy between drought, heatwaves and fuel on the 2007 southern Greece exceptional fire season. Agric Forest Meteorol 218:135-145. https://doi.org/10.1016/j. agrformet.2015.11.023

Gouveia C, Trigo R, Beguería S, Vicente-Serrano SM (2017) Drought impacts on vegetation activity in the Mediterranean region: an assessment using remote sensing data and multi-scale drought indicators. Global Planet Change 151:15-27. https://doi.org/10. 1016/j.gloplacha.2016.06.011

Guiot J, Cramer W (2016) Climate change: the 2015 Paris agreement thresholds and Mediterranean basin ecosystems. Science 354(6311):465-468. https://doi.org/10.1126/science.aah5015

Harmanny KS, Malek Ž (2019) Adaptations in irrigated agriculture in the Mediterranean region: an overview and spatial analysis of implemented strategies. Reg Environ Change 19(5):1401-1416. https://doi.org/10.1007/s10113-019-01494-8

Haylock M, Hofstra N, Tank AK, Klok E, Jones P, New M (2008) A European daily high-resolution gridded data set of surface temperature and precipitation for 1950-2006. J Geophys Res 113(D20). https://doi.org/10.1029/2008JD010201

Hernandez C, Drobinski P, Turquety S (2015) How much does weather control fire size and intensity in the Mediterranean region? Ann Geophys 33(7):931-939. https://doi.org/10.5194/ angeo-33-931-2015

Herwehe JA, Alapaty K, Spero TL, Nolte CG (2014) Increasing the credibility of regional climate simulations by introducing subgridscale cloud-radiation interactions. J Geophys Res 119(9):53175330. https://doi.org/10.1002/2014JD021504

Hoerling M, Eischeid J, Perlwitz J, Quan X, Zhang T, Pegion P (2012) On the increased frequency of Mediterranean drought. J Clim 25(6):2146-2161. https://doi.org/10.1175/JCLI-D-11-00296.1

Hofstra N, Haylock M, New M, Jones PD (2009) Testing E-OBS European high-resolution gridded data set of daily precipitation and surface temperature. J Geophys Res 114(D21). https://doi.org/10. 1029/2009JD011799

Hong SY, Dudhia J, Chen SH (2004) A revised approach to ice microphysical processes for the bulk parameterization of clouds and precipitation. Mon Weather Rev 132(1):103-120. https://doi.org/ 10.1175/1520-0493(2004)132<0103:ARATIM>2.0.CO;2

Iacono MJ, Delamere JS, Mlawer EJ, Shephard MW, Clough SA, Collins WD (2008) Radiative forcing by long-lived greenhouse gases: calculations with the AER radiative transfer models. J Geophys Res 113(D13). https://doi.org/10.1029/2008JD009944

Ioannidis E, Lolis C, Papadimas C, Hatzianastassiou N, Bartzokas A (2018) On the intra-annual variation of cloudiness over the Mediterranean region. Atmos Res 208:246-256. https://doi.org/ 10.1016/j.atmosres.2017.08.021

Jones PD, Jonsson T, Wheeler D (1997) Extension to the north Atlantic oscillation using early instrumental pressure observations from Gibraltar and south-west Iceland. Int J Climatol 17(13):14331450. https://doi.org/10.1002/(SICI)1097-0088(19971115)17:13< 1433::AID-JOC203>3.0.CO;2-P

Kain JS (2004) The Kain-Fritsch convective parameterization: an update. J Appl Meteorol 43(1):170-181. https://doi.org/10.1175/ 1520-0450(2004)043<0170:TKCPAU>2.0.CO;2

Katragkou E, García Díez M, Vautard R, Sobolowski SP, Zanis P, Alexandri G, Cardoso RM, Colette A, Fernández Fernández J, Gobiet A et al (2015) Regional climate hindcast simulations within EURO-CORDEX: evaluation of a WRF multi-physics ensemble. Geosci Model Dev 8:603-618. https://doi.org/10.5194/ gmd-8-603-2015

Knyazikhin Y, Martonchik J, Myneni RB, Diner D, Running SW (1998) Synergistic algorithm for estimating vegetation canopy leaf area index and fraction of absorbed photosynthetically active radiation from modis and misr data. J Geophys Res 103(D24):3225732275. https://doi.org/10.1029/98JD02462

Krinner G, Viovy N, de Noblet-Ducoudré N, Ogée J, Polcher J, Friedlingstein P, Ciais P, Sitch S, Prentice IC (2005) A dynamic global vegetation model for studies of the coupled atmospherebiosphere system. Global Biogeochem Cycles 19(1). https://doi. org/10.1029/2003GB002199 
Lhotka O, Kyselỳ J (2015) Characterizing joint effects of spatial extent, temperature magnitude and duration of heat waves and cold spells over central europe. Int J Climatol 35(7):1232-1244. https://doi. org/10.1002/joc. 4050

Maignan F, Bréon FM, Chevallier F, Viovy N, Ciais P, Garrec C, Trules J, Mancip M (2011) Evaluation of a global vegetation model using time series of satellite vegetation indices. Geosci Model Dev 4(4):1103-1114. https://doi.org/10.5194/gmd-4-1103-2011

McKee TB, Doesken NJ, Kleist J, et al. (1993) The relationship of drought frequency and duration to time scales. In: Proceedings of the 8th conference on applied climatology, vol 17. American Meteorological Society, Boston, pp 179-183

Moriondo M, Good P, Durao R, Bindi M, Giannakopoulos C, CorteReal J (2006) Potential impact of climate change on fire risk in the Mediterranean area. Clim Res 31(1):85-95. https://doi.org/ $10.3354 / \mathrm{cr} 031085$

Myneni R, Knyazikhin Y, Park T (2015) MOD15A2H MODIS/Terra Leaf Area Index/FPAR 8-day L4 Global 500 m SIN Grid V006. NASA EOSDIS Land Processes DAAC. https://modis.gsfc.nasa. gov/data/dataprod/mod15.php

Nakanishi M, Niino H (2009) Development of an improved turbulence closure model for the atmospheric boundary layer. J Meteorol Soc Jpn Ser II 87(5):895-912. https://doi.org/10.2151/ jmsj.87.895

Omrani H, Drobinski P, Dubos T (2015) Using nudging to improve global-regional dynamic consistency in limited-area climate modeling: what should we nudge? Clim Dyn 44(5-6):1627-1644. https://doi.org/10.1007/s00382-014-2453-5

Park S, Bretherton CS (2009) The University of Washington shallow convection and moist turbulence schemes and their impact on climate simulations with the community atmosphere model. J Clim 22(12):3449-3469. https://doi.org/10.1175/2008JCLI2557.1

Pfeifroth U, Sanchez-Lorenzo A, Manara V, Trentmann J, Hollmann R (2018) Trends and variability of surface solar radiation in Europe based on surface-and satellite-based data records. J Geophys Res 123(3):1735-1754. https://doi.org/10.1002/2017JD027418

Philandras C, Nastos P, Kapsomenakis J, Douvis K, Tselioudis G, Zerefos C (2011) Long term precipitation trends and variability within the Mediterranean region. Nat Hazards Earth Syst Sci 11(12):3235-3250. https://doi.org/10.5194/nhess-11-3235-2011

Polcher J, McAvaney B, Viterbo P, Gaertner MA, Hahmann A, Mahfouf JF, Noilhan J, Phillips T, Pitman A, Schlosser C et al (1998) A proposal for a general interface between land surface schemes and general circulation models. Global Planet Change 19(14):261-276. https://doi.org/10.1016/S0921-8181(98)00052-6

Raymond F, Ullmann A, Camberlin P, Drobinski P, Smith CC (2016) Extreme dry spell detection and climatology over the Mediterranean basin during the wet season. Geophys Res Lett 43(13):71967204. https://doi.org/10.1002/2016GL069758

Raymond F, Ullmann A, Camberlin P, Oueslati B, Drobinski P (2018) Atmospheric conditions and weather regimes associated with extreme winter dry spells over the Mediterranean basin. Clim Dyn 50(11-12):4437-4453. https://doi.org/10.1007/ s00382-017-3884-6

Rivoire P, Tramblay Y, Neppel L, Hertig E, Vicente-Serrano SM (2019) Impact of the dry day definition on Mediterranean extreme dry spells analysis. Nat Hazard Earth Syst Sci. https://doi.org/10. 5194/nhess-19-1629-2019

Russo S, Sillmann J, Fischer EM (2015) Top ten European heatwaves since 1950 and their occurrence in the coming decades. Environ Res Lett 10(12):124003. https://doi.org/10.1088/1748-9326/10/ $12 / 124003$

Ruti PM, Somot S, Giorgi F, Dubois C, Flaounas E, Obermann A, Dell'Aquila A, Pisacane G, Harzallah A, Lombardi E et al (2016) Med-CORDEX initiative for mediterranean climate studies. Bull
Am Meteorol Soc 97(7):1187-1208. https://doi.org/10.1175/ BAMS-D-14-00176.1

San-Miguel-Ayanz J, Schulte E, Schmuck G, Camia A, Strobl P, Liberta G, Giovando C, Boca R, Sedano F, Kempeneers P et al (2012) Comprehensive monitoring of wildfires in Europe: the European forest fire information system (EFFIS). In: Approaches to managing disaster-assessing hazards, emergencies and disaster impacts. IntechOpen. https://doi.org/10.5772/28441

Sarris D, Christopoulou A, Angelonidi E, Koutsias N, Fulé PZ, Arianoutsou M (2014) Increasing extremes of heat and drought associated with recent severe wildfires in southern Greece. Reg Environ Change 14(3):1257-1268. https://doi.org/10.1007/ s10113-013-0568-6

Skamarock WC, Klemp JB, Dudhia J, Gill DO, Barker DM, Wang W, Powers JG (2008) A description of the advanced research WRF version 3. NCAR/TN-475+str. Tech. rep. https://doi.org/10.5065/ D68S4MVH

Spinoni J, Naumann G, Vogt JV, Barbosa P (2015) The biggest drought events in Europe from 1950 to 2012. J Hydrol Reg Stud 3:509 524. https://doi.org/10.1016/j.ejrh.2015.01.001

Spinoni J, Vogt JV, Naumann G, Barbosa P, Dosio A (2018) Will drought events become more frequent and severe in Europe? Int $\mathrm{J}$ Climatol 38(4):1718-1736. https://doi.org/10.1002/joc.5291

Sprintsin M, Karnieli A, Berliner P, Rotenberg E, Yakir D, Cohen S (2009) Evaluating the performance of the MODIS leaf area index (LAI) product over a Mediterranean dryland planted forest. Int J Remote Sens 30(19):5061-5069. https://doi.org/10.1080/01431 160903032885

Stéfanon M, Drobinski P, D’Andrea F, Noblet-Ducoudré N (2012a) Effects of interactive vegetation phenology on the 2003 summer heat waves. J Geophys Res 117(D24). https://doi.org/10.1029/ 2012JD018187

Stéfanon M, D’Andrea F, Drobinski P (2012b) Heatwave classification over Europe and the Mediterranean region. Environ Res Lett 7(1):014023. https://doi.org/10.1088/1748-9326/7/1/014023

Stéfanon M, Drobinski P, D'Andrea F, Lebeaupin-Brossier C, Bastin S (2014) Soil moisture-temperature feedbacks at meso-scale during summer heat waves over western Europe. Clim Dyn 42(56):1309-1324. https://doi.org/10.1007/s00382-013-1794-9

Stegehuis AI, Vautard R, Ciais P, Teuling AJ, Jung M, Yiou P (2013) Summer temperatures in Europe and land heat fluxes in observation-based data and regional climate model simulations. Clim Dyn 41(2):455-477. https://doi.org/10.1007/s00382-012-1559-x

Svoboda M, Fuchs B et al (2016) Handbook of drought indicators and indices. Drought Mitigation Center Faculty Publications, 117. http://digitalcommons.unl.edu/droughtfacpub/117

Trigo RM, Pozo-Vázquez D, Osborn TJ, Castro-Díez Y, Gámiz-Fortis S, Esteban-Parra MJ (2004) North Atlantic oscillation influence on precipitation, river flow and water resources in the Iberian peninsula. Int J Climatol 24(8):925-944. https://doi.org/10.1002/ joc. 1048

Turco M, Bedia J, Di Liberto F, Fiorucci P, von Hardenberg J, Koutsias N, Llasat MC, Xystrakis F, Provenzale A (2016) Decreasing fires in Mediterranean Europe. PLoS One 11(3):e0150663. https://doi. org/10.1371/journal.pone.0150663

Turco M, von Hardenberg J, AghaKouchak A, Llasat MC, Provenzale A, Trigo RM (2017) On the key role of droughts in the dynamics of summer fires in Mediterranean Europe. Sci Rep 7(1):81. https:// doi.org/10.1038/s41598-017-00116-9

Turco M, Herrera S, Tourigny E, Chuvieco E, Provenzale A (2019) A comparison of remotely-sensed and inventory datasets for burned area in Mediterranean Europe. Int J Appl Earth Observ Geoinf 82:101887. https://doi.org/10.1016/j.jag.2019.05.020

Turquety S, Menut L, Siour G, Mailler S, Hadji-Lazaro J, George M, Clerbaux C, Hurtmans D, Coheur PF (2020) Apiflame v2.0 biomass burning emissions model: impact of refined input parameters 
on atmospheric concentration in Portugal in summer 2016. Geosci Model Dev 13(7):2981-3009. https://doi.org/10.5194/ gmd-13-2981-2020

Vautard R, Yiou P, D'andrea F, De Noblet N, Viovy N, Cassou C, Polcher J, Ciais P, Kageyama M, Fan Y (2007) Summertime European heat and drought waves induced by wintertime Mediterranean rainfall deficit. Geophys Res Lett 34(7). https://doi.org/10. 1029/2006GL028001

Vicente-Serrano SM (2007) Evaluating the impact of drought using remote sensing in a Mediterranean, semi-arid region. Nat Hazards 40(1):173-208. https://doi.org/10.1007/s11069-006-0009-7

Vicente-Serrano SM, Beguería S, López-Moreno JI (2010) A multiscalar drought index sensitive to global warming: the standardized precipitation evapotranspiration index. J Clim 23(7):1696-1718. https://doi.org/10.1175/2009JCLI2909.1

Vicente-Serrano SM, Beguería S, Lorenzo-Lacruz J, Camarero JJ, López-Moreno JI, Azorin-Molina C, Revuelto J, Morán-Tejeda E, Sanchez-Lorenzo A (2012) Performance of drought indices for ecological, agricultural, and hydrological applications. Earth Interact 16(10):1-27. https://doi.org/10.1175/2012EI000434.1

Vicente-Serrano SM, Gouveia C, Camarero JJ, Beguería S, Trigo R, López-Moreno JI, Azorín-Molina C, Pasho E, Lorenzo-Lacruz J,
Revuelto J et al (2013) Response of vegetation to drought timescales across global land biomes. Proc Natl Acad Sci 110(1):5257. https://doi.org/10.1073/pnas.1207068110

Xoplaki E, González-Rouco J, Luterbacher J, Wanner H (2004) Wet season Mediterranean precipitation variability: influence of largescale dynamics and trends. Clim Dyn 23(1):63-78. https://doi.org/ 10.1007/s00382-004-0422-0

Zampieri M, D'Andrea F, Vautard R, Ciais P, de Noblet-Ducoudré N, Yiou P (2009) Hot European summers and the role of soil moisture in the propagation of Mediterranean drought. J Clim 22(18):4747-4758. https://doi.org/10.1175/2009JCLI2568.1

Zampieri M, Ceglar A, Dentener F, Toreti A (2017) Wheat yield loss attributable to heat waves, drought and water excess at the global, national and subnational scales. Environ Res Lett 12(6):064008. https://doi.org/10.1088/1748-9326/aa723b

Publisher's Note Springer Nature remains neutral with regard to jurisdictional claims in published maps and institutional affiliations. 